\title{
Identification of Streptococcus thermophilus Genes Specifically Expressed under Simulated Human Digestive Conditions Using R-IVET Technology
}

\author{
Ophélie Uriot ${ }^{1,2}$, Mounira Kebouchi ${ }^{1}$, Emilie Lorson ${ }^{1}$, Wessam Galia ${ }^{1,3}{ }^{(}$, , Sylvain Denis ${ }^{2}$, Sandrine Chalancon ${ }^{2}$, \\ Zeeshan Hafeez ${ }^{1}$, Emeline Roux $\left.{ }^{1,4}{ }^{(}\right)$, Magali Genay $\left.{ }^{1}{ }^{(}\right)$, Stéphanie Blanquet-Diot ${ }^{2, \dagger}$ and Annie Dary-Mourot ${ }^{1, *,+}$ \\ 1 EA 7488 Calbinotox Composés Alimentaires Biofonctionnalités \& Risque Neurotoxique, \\ Université de Lorraine, 54506 Vandoeuvre-lès-Nancy, France; ophelie.uriot@uca.fr (O.U.); \\ mounira.kebouchi@hotmail.fr (M.K.); emilie.lorson@univ-lorraine.fr (E.L.); \\ wessam.galia@vetagro-sup.fr (W.G.); zeeshan.hafeez@univ-lorraine.fr (Z.H.); \\ emeline.roux@univ-lorraine.fr (E.R.); magali.genay@univ-lorraine.fr (M.G.) \\ 2 UMR 454 MEDIS Microbiology, Digestive Environment and Health, Université Clermont Auvergne, INRAe, \\ 63000 Clermont-Ferrand, France; sylvain.denis@uca.fr (S.D.); sandrine.chalancon@uca.fr (S.C.); \\ stephanie.blanquet@uca.fr (S.B.-D.) \\ 3 UMR 5557 Microbial Ecology, Research Group on Bacterial Opportunistic Pathogens and Environment, \\ CNRS, VetAgro Sup, 69280 Marcy L'Etoile, France \\ 4 INRIA/IRISA, GenScale Bioinformatics Team, 35042 Rennes, France \\ * Correspondence: annie.dary@univ-lorraine.fr \\ + Co-senior authors.
}

Citation: Uriot, O.; Kebouchi, M.; Lorson, E.; Galia, W.; Denis, S.; Chalancon, S.; Hafeez, Z.; Roux, E.; Genay, M.; Blanquet-Diot, S.; et al. Identification of Streptococcus thermophilus Genes Specifically Expressed under Simulated Human Digestive Conditions Using R-IVET Technology. Microorganisms 2021, 9 , 1113. https://doi.org/10.3390/ microorganisms 9061113

Academic Editor: Harsharn Gill

Received: 7 May 2021

Accepted: 19 May 2021

Published: 21 May 2021

Publisher's Note: MDPI stays neutral with regard to jurisdictional claims in published maps and institutional affiliations.

Copyright: () 2021 by the authors. Licensee MDPI, Basel, Switzerland. This article is an open access article distributed under the terms and conditions of the Creative Commons Attribution (CC BY) license (https:// creativecommons.org/licenses/by/ $4.0 /)$.
Abstract: Despite promising health effects, the probiotic status of Streptococcus thermophilus, a lactic acid bacterium widely used in dairy industry, requires further documentation of its physiological status during human gastrointestinal passage. This study aimed to apply recombinant-based in vivo technology (R-IVET) to identify genes triggered in a S. thermophilus LMD-9 reference strain under simulated digestive conditions. First, the R-IVET chromosomal cassette and plasmid genomic library were designed to positively select activated genes. Second, recombinant clones were introduced into complementary models mimicking the human gut, the Netherlands Organization for Applied Scientific Research (TNO) gastrointestinal model imitating the human stomach and small intestine, the Caco-2 TC7 cell line as a model of intestinal epithelium, and anaerobic batch cultures of human feces as a colon model. All inserts of activated clones displayed a promoter activity that differed from one digestive condition to another. Our results also showed that $S$. thermophilus adapted its metabolism to stressful conditions found in the gastric and colonic competitive environment and modified its surface proteins during adhesion to Caco-2 TC7 cells. Activated genes were investigated in a collection of $S$. thermophilus strains showing various resistance levels to gastrointestinal stresses, a first stage in the identification of gut resistance markers and a key step in probiotic selection.

Keywords: S. thermophilus; R-IVET; TIM-1 system; intestinal microbiota; adhesion

\section{Introduction}

The lactic acid bacterium Streptococcus thermophilus is widely used as a starter for yogurt and cheese production, mainly for its ability to produce lactic acid and secondary fermentation products with aromatic and textural properties [1]. It has a very long history of use in dairy industry without any identified health problem. Furthermore, virulence-related genes are absent from its genome [2]. Hence, it has been assigned the generally recognized as safe (GRAS) and qualified presumption of safety (QPS) status by the American Food and Drug Administration and European Food Safety Authority (EFSA), respectively. In spite of its very large human consumption and the health claim attributed by EFSA to live yogurt cultures (S. thermophilus and Lactobacillus delbrueckii) to improve lactose digestion [3], the probiotic status of $S$. thermophilus strains is still poorly explored $[4,5]$. 
Probiotics are defined as "live micro-organisms that, when administered in adequate amounts, confer a health benefit on the host" [5,6]. The main criteria to select probiotics include (i) resistance to stresses encountered in the human gastrointestinal (GI) tract such as acidic $\mathrm{pH}$ and bile salts, and (ii) beneficial impacts on host health. Few studies have already shown that $S$. thermophilus can survive passage through the human gut [7-10]. Nevertheless, it must be underlined that bacterial counts were mostly performed in the feces of human volunteers, not along the entire GI tract, and after consumption of yogurts containing both $S$. thermophilus and L. delbrueckii, which can affect survival of individual strains. Although survival of probiotics in the human gut involves resistance to main GI stresses, capacity to adhere to intestinal epithelial cells may also contribute to their persistence in the GI tract by promoting a transient intestinal colonization [11,12]. In vitro studies have shown that few strains of $S$. thermophilus, especially the LMD-9 reference strain, are able to adhere to several types of human intestinal epithelial cell lines [13-16]. Regarding health effects, in vitro studies and in vivo experiments in rodents have shown that $S$. thermophilus possesses interesting properties (in addition to lactose digestion improvement) such as prevention of chronic gastritis and antimicrobial or antioxidant activities, as reviewed by Uriot et al. [17]. Interestingly, it was shown that all these properties were largely straindependent $[15,18,19]$. Consequently, additional information on the survival and metabolic status of this bacterium in the human digestive environment is compulsory before assigning any probiotic allegation.

Several global approaches can be employed to address the metabolic status of $S$. thermophilus in the digestive tract, such as DNA microrarray, RNA-sequencing, or proteomics, but few studies have been done. Only two proteomics investigations have been performed to attempt to establish the physiological status of $S$. thermophilus during passage through the GI tract. Results have highlighted the importance of the glycolysis pathway $[20,21]$. Nevertheless, these studies were carried out in gnotobiotic rats, a model that is far from the complex human GI tract physiology. Another strategy based on analysis of the bacterial transcriptome is the recombinase-based in vivo expression technology (R-IVET). R-IVET is a promoter-trapping technology that consists of two elements: (i) a plasmid containing a promoterless recombinase gene (often the gene cre) upstream of which genomic DNA fragments are inserted, and (ii) a chromosomal cassette with at least an antibiotic resistance gene flanked by recognition sites (often the loxP sequences, recognized by the recombinase Cre) of plasmid-encoded recombinase. Therefore, if a genomic DNA fragment inserted upstream of the recombinase gene displays promoter activity (activated R-IVET recombinant clone), the recombinase is expressed and the antibiotic resistance gene located in the chromosomal cassette is excised [22,23]. The R-IVET approach has already been developed in different bacteria, such as Bifidobacterium longum, Lactobacillus plantarum, Vibrio cholerae, and S. thermophilus [23-27]. Up to now, this technique was used to follow gene expression in complex digestive media, but mainly when using mice models [24-27]; alternatively, in a unique previous study by our team, it was used to assess the behavior of the $S$. thermophilus LMD-9 reference strain under simulated human gastric conditions [18]. However, this technology is often limited by its screening phase. Most of the time, a single resistance gene inside the chromosomal cassette results in a cumbersome selection of activated clones, leading to a heavy and time-consuming negative screening.

The aim of this work was (i) to optimize the R-IVET tool for S. thermophilus LMD-9 by designing and validating a chromosomal cassette that allows a positive screening of activated recombinant R-IVET clones, and (ii) to use the R-IVET approach to identify which S. thermophilus LMD-9 genes are specifically activated during transit through the entire simulated human GI tract. In an original and global approach, we used, for the first time, three complementary in vitro human gut models: (i) the dynamic multicompartmental Netherlands Organization for Applied Scientific Research (TNO) gastrointestinal model (TIM-1), which is currently the most complete simulator of physicochemical conditions found in the human stomach and small intestine [28-30], (ii) the Caco-2 TC7 cell line which exhibits a morphological and functional enterocyte phenotype closed to that found 
in humans (for a review, see [31]) as a model of bacterial adhesion to human intestinal epithelial cells, and (iii) anaerobic batch cultures of human feces as a simplified model of the human colon.

\section{Materials and Methods}

\subsection{Bacterial Strains, Culture, and Transformation Conditions}

Bacterial strains and plasmids used in the present study are listed in Table 1. S. thermophilus LMD-9 from the American Type Culture Collection (Manassas, VA, USA) was used to implement the R-IVET system. S. thermophilus strains were stored at $-80{ }^{\circ} \mathrm{C}$ in reconstituted skim milk $(10 \%, w / v)$. They were grown at $42{ }^{\circ} \mathrm{C}$ under anaerobic conditions (AnaeroGen, Oxoid, Basingstoke, UK) in M17 medium [32] supplemented with 2\% $(w / v)$ lactose (LM17) or in 10\% (w/v) reconstituted milk (powdered semi-skimmed milk, fast dissolution, Régilait). Unless otherwise specified, antibiotics (Sigma, Saint Quentin Fallavier, France) were added at the following concentrations: spectinomycin $300 \mu \mathrm{g} / \mathrm{mL}$, streptomycin $20 \mu \mathrm{g} / \mathrm{mL}$, kanamycin $1 \mathrm{mg} / \mathrm{mL}$, or erythromycin $5 \mu \mathrm{g} / \mathrm{mL}$. S. thermophilus naturally competent cells were prepared in Chemically Defined Medium (CDM) as previously described [33] and transformed according to Junjua et al. [23]. For long-term storage at $-80{ }^{\circ} \mathrm{C}$, competent cells were centrifuged, resuspended in $1 / 10$ volume of the initial culture supplemented with glycerol (14\%), and frozen in liquid nitrogen. As S. thermophilus develops in the form of coccus chains, samples were systematically vigorously vortexed for 3 min to break the chains before spreading on solid medium. This step was to ensure that each colony observed after incubation at $42{ }^{\circ} \mathrm{C}$ probably came from a single cell.

Table 1. Bacterial strains and plasmids used in the present study.

\begin{tabular}{|c|c|c|}
\hline Strain or Plasmid & Relevant Markers and Characteristics & Reference or Source \\
\hline \multicolumn{3}{|l|}{ Strains } \\
\hline S. thermophilus CNRZ160 & $\begin{array}{l}\text { Wild-type strain whose genome has been } \\
\text { entirely sequenced }\end{array}$ & $\begin{array}{l}\text { STH_CIRM_16 } \\
\text { CNRZ collection }\end{array}$ \\
\hline S. thermophilus CNRZ21 & Wild-type strain & CNRZ collection, Nancy subclone \\
\hline S. thermophilus EBL308 & Wild-type strain & Laboratory collection \\
\hline S. thermophilus EBL385 & Wild-type strain & Laboratory collection \\
\hline S. thermophilus EBLST20 & Wild-type strain & Laboratory collection \\
\hline S. thermophilus LMD-9 & $\begin{array}{c}\text { Wild-type strain whose genome has been } \\
\text { entirely sequenced }\end{array}$ & $\begin{array}{l}\text { ATCC BAA- } 491 \\
{[34]}\end{array}$ \\
\hline S. thermophilus LMG18311 & $\begin{array}{l}\text { Wild-type strain whose genome has been } \\
\text { entirely sequenced }\end{array}$ & $\begin{array}{l}\text { ATCC BAA- } 250 \\
{[2]}\end{array}$ \\
\hline S. thermophilus PB18O & Wild-type strain & Laboratory collection \\
\hline S. thermophilus PB302 & Wild-type strain & Laboratory collection \\
\hline S. thermophilus PB385 & Wild-type strain & Laboratory collection \\
\hline S. thermophilus PB5MJ & Wild-type strain & Laboratory collection \\
\hline S. thermophilus ST14 & Wild-type strain & Laboratory collection \\
\hline S. thermophilus ST88 & Wild-type strain & Laboratory collection \\
\hline S. thermophilus STUL5002 & $\begin{array}{l}\text { LMD-9 derivative with the prom-loxP-kanR } \\
\text { fragment in the STER_0891 locus } \\
\text { (STER_RS04415) }\end{array}$ & Present study \\
\hline S. thermophilus STUL5003 & $\begin{array}{l}\text { LMD-9 derivative with the } \\
\text { prom-loxP-specR-loxP-kanR fragment in the } \\
\text { STER_0891 locus (STER_RS04415) }\end{array}$ & Present study \\
\hline S. thermophilus TIL1193 & LMD-9 feoB::aphA3 & [33] \\
\hline E. coli TOP10 & $\begin{array}{c}\text { One Shot }{ }^{\circledR} \text { TOP10 chemically competent } E . \\
\text { coli cells }\end{array}$ & Invitrogen \\
\hline \multicolumn{3}{|c|}{ 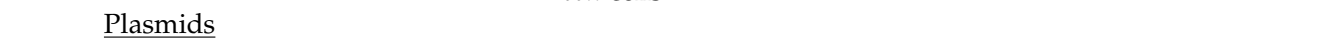 } \\
\hline pULNcreB & $\begin{array}{l}\text { pG }{ }^{+} \text {host } 9^{\mathrm{TR}} \text { derivative containing } \\
\text { promoterless recombinase } \text { cre gene }\end{array}$ & [23] \\
\hline pSET4S & $\begin{array}{l}\text { Replication function of } \mathrm{pG}^{+} \text {host3 and } \\
\text { pUC19 }\end{array}$ & {$[35]$} \\
\hline pULNcreB-plac & $\begin{array}{l}\text { pULNcreB derivative containing the } \\
\text { promoter of the lactose operon plac cloned } \\
\text { in the } B g l \mathrm{II} \text { site upstream of } \mathrm{cre}\end{array}$ & [23] \\
\hline
\end{tabular}


E. coli TOP10 (Invitrogen, Breda, The Netherlands) was used as an intermediate cloning host and was grown in aerobic conditions at $37{ }^{\circ} \mathrm{C}$ in Luria-Bertani (LB) medium under shaking at $240 \mathrm{rpm}$, supplemented or not with erythromycin $300 \mu \mathrm{g} / \mathrm{mL}$. Chemical transformation of this strain was performed according to manufacturer's instructions.

\subsection{DNA Extraction, Digestion, and PCR Amplification}

S. thermophilus genomic DNA was extracted as previously described by Fischer et al. [36], and restriction digestions were performed following the manufacturer's instructions. Polymerase chain reactions (PCR) were carried out in a Mastercycler pro thermocycler (Eppendorf, Hambourg, Germany). Oligonucleotides used as primers were purchased from Eurogentec (Seraing, Belgium), and their sequences are described in Table S1 (Supplementary Materials). Classic and overlapping PCRs were performed using enzymes and conditions previously described by Junjua et al. [23]. DNA fragments were separated by electrophoresis in $1 \%$ agarose gels using $0.5 \times$ Tris-Borate EDTA buffer at $100 \mathrm{~V}$ [37]. Molecular weight marker $1 \mathrm{~kb}$ and $100 \mathrm{bp}$ DNA ladders from Fermentas were used. Gels were stained with ethidium bromide and imaged using a GelDoc-It Imaging System (Bio-Rad, Marne-laCoquette, France).

\subsection{Construction of R-IVET Chromosomal Cassette and S. thermophilus Mutant STUL5003}

The strategy used to construct the $S$. thermophilus STUL5003 mutant strain containing the chromosomal prom-loxP-specR-Tlas-loxP-kanR cassette is presented in Figure 1. In a first series of PCR (Figure 1A-C), the intermediate strain STUL5002 was built from $S$. thermophilus LMD-9. This mutant strain contained a chromosomal cassette consisting of the $k a n R$ gene, encoding a $3^{\prime} 5^{\prime}$-aminoglycoside phosphotransferase of type III (aphA3), separated from its own promoter by a loxP site (Figure 1C). The presence of loxP did not preclude the expression of the kanR gene. To obtain the cassette, a series of PCRs was carried out as follows: amplification of the UP\#1 and DOWN\#1 fragments from genomic DNA of S. thermophilus LMD-9, and of the prom (promoter region of the kanR gene) and loxP-kanR fragments (Figure 1A) from genomic DNA of S. thermophilus TIL1193 (Table 1) [33]. The four fragments UP\#1, prom, loxP-kanR, and DOWN\#1 were amplified individually using primer couples \#1\#2,\#3\#4,\#5\#6, and \#7\#8, respectively (Figure 1A). Then, an overlapping PCR was carried out using primer couples \#1\#8 and the four fragments UP\#1, prom, loxP$k a n R$, and DOWN\#1 mixed together in equimolar concentrations (Figure 1B). About $30 \mathrm{ng}$ of the resulting amplified fragments were used for transformation of LMD-9 competent cells. A kanamycin-resistant clone was selected and confirmed to have the prom-loxP-kanR fragment at the STER_0891 locus by colony PCR using the primer couple \#9\#10 (Figure 1C). The resulting mutant strain was named STUL5002. The prom-loxP-kanR fragment and chromosomal junctional regions were sequenced to check that no mutation occurred during this mutant construction.

In a second series of PCR (Figure 1D-F), strain STUL5003 containing a prom-loxPspecR-Tlas-loxP-kanR chromosomal cassette was built. The four fragments UP\#2, specR, Tlas, and loxP-DOWN\#2 were individually amplified using primer couples \#11\#12,\#13\#14, $\# 15 \# 16$ and \#17\#6, respectively (Figure 1D). Genomic DNA of strain STUL5002 was used as template to amplify the UP\#2 and loxP-DOWN\#2 fragments. The terminator Tlas fragment was amplified from the pULNcreB plasmid [23]. The plasmid pSET4S (Table 1, [35]) was used to amplify the $s p e c R$ gene encoding a spectinomycin adenyltransferase. Once obtained, fragments UP\#2, specR, Tlas, and loxP-DOWN\#2 were mixed together in equimolar concentrations, and an overlapping PCR was carried out using primer couple \#11\#6 (Figure 1E). About $30 \mathrm{ng}$ of the resulting amplified fragments were used for transformation of STUL5002 competent cells (Figure 1F). Among the spectinomycin-resistant transformants, three were randomly selected, and the construction was sequenced in each to confirm the presence of the expected chromosomal cassette. Hence, one of them was chosen and named STUL5003. This strain displayed a $\operatorname{Spec}^{\mathrm{R}} \mathrm{Kan}^{\mathrm{S}}$ phenotype as expected. 
A)

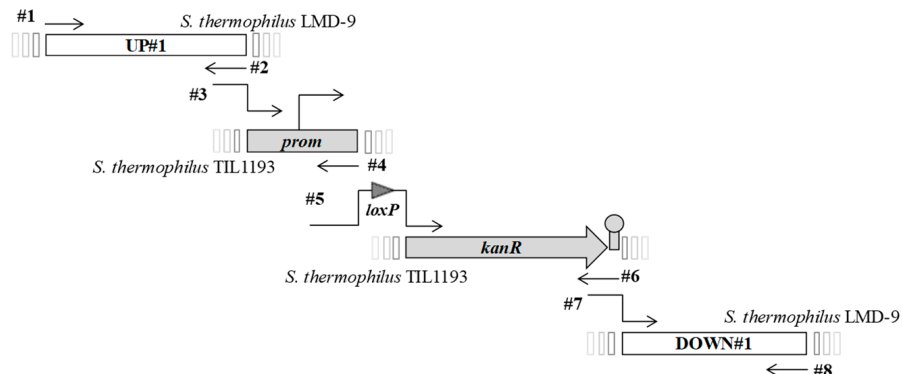

B)

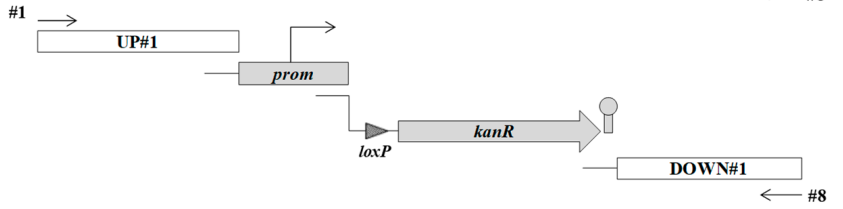

C)

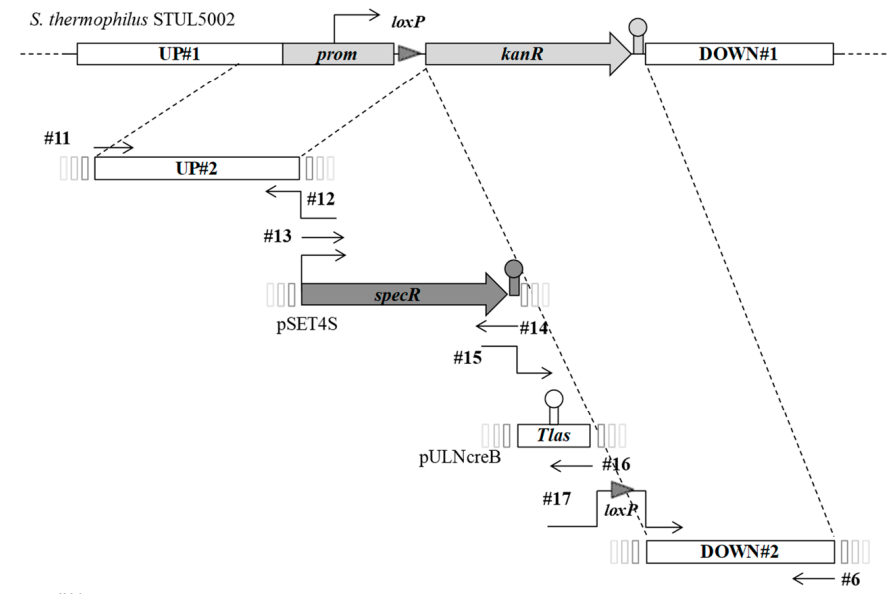

E)

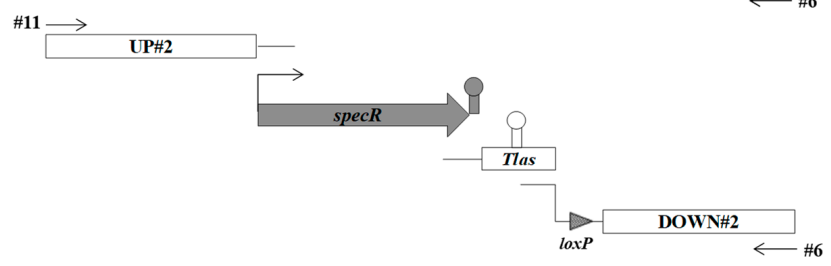

F)

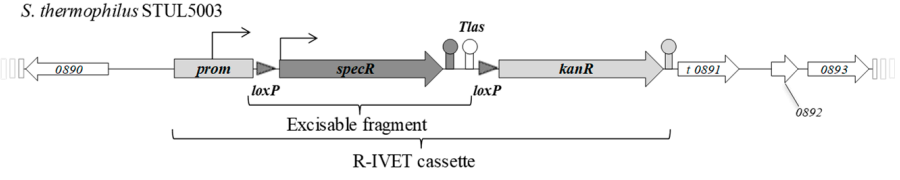

Figure 1. Construction of the chromosomal R-IVET cassette. The R-IVET chromosomal construction was cloned into the locus STER 0891 (t0891) of S. thermophilus LMD-9 resulting in strain STUL5003. This strain was constructed in two steps. The first step (1A to 1C) corresponds to the construction of STUL5002 mutant: PCR amplification of individual fragments (A), overlapping PCR (B), and resulting construction on the chromosome of STUL5002 mutant (C). The second step (1D to 1F) illustrates the construction of STUL5003 mutant: PCR amplification of individual fragments (D), overlapping PCR (E), and resulting chromosomal construction of STUL5003 mutant (F). Numerical values indicated in italics in genes $(\mathbf{F})$ correspond to locus tags as described in the annotated sequence of LMD-9 chromosome (NC_008532_1). Oligonucleoti0des used as amplification primers are indicated as black arrows and are labeled with their \# numbers (see Table S1, Supplementary Materials). UP and DOWN regions correspond to upstream and downstream sequences flanking the fragments to be cloned, respectively. The $\operatorname{spec} R, k a n R$, and prom fragments correspond to genes encoding a spectinomycin adenyltransferase conferring resistance to spectinomycin and streptomycin, a $3^{\prime} 5^{\prime \prime}$-aminoglycoside phosphotransferase of type III conferring resistance to kanamycin, and the promoter region of kanR gene, respectively. The gray triangle corresponds to the loxP sequence that is recognized by the specific site recombinase Cre. 


\subsection{R-IVET Genomic Library Construction}

Digestion with $A l u$ I and SmaI restriction enzymes, ligation with the $\mathrm{T}_{4} \mathrm{DNA}$ ligase, and dephosphorylation using calf intestinal alkaline phosphatase were performed according to the supplier's recommendations (New England Biolabs, Leiden, The Netherlands). The RIVET library was constructed in the STUL5003 strain. The genomic DNA of $S$. thermophilus LMD-9 was partially digested with $A l u \mathrm{I}$, and restriction fragments were ligated with the pULNcreB plasmid, which was previously linearized by SmaI and dephosphorylated. DNA digestions were checked by agarose gel electrophoresis and were purified using the High Pure DNA purification Kit (Roche Molecular Biochemicals, Mannheim, Germany) according to the manufacturer's recommendations. Chemically competent cells of E. coli TOP10 were transformed with the ligated plasmids. All resulting clones were pooled and their plasmid DNAs extracted using a Miniprep Kit (Fermentas, Villebon sur Yvette, France). Plasmid DNAs were then introduced by natural transformation into $S$. thermophilus STUL5003. The resulting $S$. thermophilus clones were selected on LM17 supplemented with streptomycin, pooled, resuspended into LM17 supplemented with $11.6 \%$ glycerol, and stored in aliquots at $-80^{\circ} \mathrm{C}$ to constitute the $S$. thermophilus R-IVET genomic library.

\subsection{Optimization of the Counterselection Condition of Activated R-IVET Clones}

To efficiently eliminate $\mathrm{Spec}^{\mathrm{S}} \mathrm{Kan}^{\mathrm{R}}$ clones obtained during the R-IVET library growth before its introduction into one of the gut models used in this work, two different antibiotic combinations were tested: spectinomycin $300 \mu \mathrm{g} / \mathrm{mL}$ or a mix of spectinomycin $300 \mu \mathrm{g} / \mathrm{mL}$ and streptomycin $20 \mu \mathrm{g} / \mathrm{mL}$. Thus, after growth in milk (medium used for TIM- 1 and fecal batch culture models) or in LM17 (Caco-2 TC7 model), cells of the R-IVET genomic library were exposed for $3 \mathrm{~h}, 7 \mathrm{~h}$, or $15 \mathrm{~h}$ to these antibiotics. Counterselection effectiveness of the $\mathrm{Spec}^{\mathrm{S}} \mathrm{Kan}^{\mathrm{R}}$ clones was then evaluated by plating appropriate dilutions of each sample on LM17 agar supplemented with erythromycin (LM17-ery), a mix of spectinomycin and streptomycin (LM17-spec/strep), or a mix of kanamycin and erythromycin (LM17-kan/ery). As the specR gene confers resistance to both spectinomycin and streptomycin, these antibiotics were used alone or together. After $3 \mathrm{~h}$ exposure to spectinomycin $300 \mu \mathrm{g} / \mathrm{mL}$ or a mix of spectinomycin $300 \mu \mathrm{g} / \mathrm{mL}$ and streptomycin $20 \mu \mathrm{g} / \mathrm{mL}, 0.15 \%$ and $0.03 \%$ of colonies plated onto LM17-ery were also present on LM17-kan/ery, respectively. The results appeared slightly better since $0.015 \%$ of colonies plated onto LM17-ery were also growing on LM17-kan/ery after $7 \mathrm{~h}$ exposure to the mix of spectinomycin $300 \mathrm{\mu g} / \mathrm{mL}$ and streptomycin $20 \mu \mathrm{g} / \mathrm{mL}$ vs. $0.08 \%$ when using spectinomycin $300 \mu \mathrm{g} / \mathrm{mL}$. Similar results were obtained after $15 \mathrm{~h}$ exposure. Moreover, for each condition of counterselection tested, 10 clones randomly selected from LM17-kan/ery plates, deletion of loxP-specR fragment from the chromosomal cassette, and presence of an insert in pULNcreB plasmid were confirmed. Therefore, it appeared that counterselection using a mix of spectinomycin/streptomycin was the most efficient. On the basis of these results and for further easy handling, it was decided to grow the R-IVET genomic library overnight in milk (TIM-1 and batch cultures) or in LM17 (adhesion) with this mix of antibiotics.

\subsection{In Vitro Digestions in the TIM-1 System}

The TIM-1 system is composed of four successive compartments, namely, the stomach, duodenum, jejunum, and ileum. This computer-controlled dynamic in vitro model accurately reproduces the main physicochemical parameters found in the stomach and small intestine in vivo (no microbiota): body temperature, kinetics of gastric and intestinal $\mathrm{pH}$, gastric, pancreatic, and liver digestive secretions, chyme transit and mixing, and passive absorption of nutrients and water (Figure 2). TIM-1 was washed with detergent and sterilized by steaming at $105^{\circ} \mathrm{C}$ for $35 \mathrm{~min}$ before each experiment to avoid any microbial contamination. In the present study, the model was programmed to reproduce digestion of milk by a healthy human adult (Table 2). 


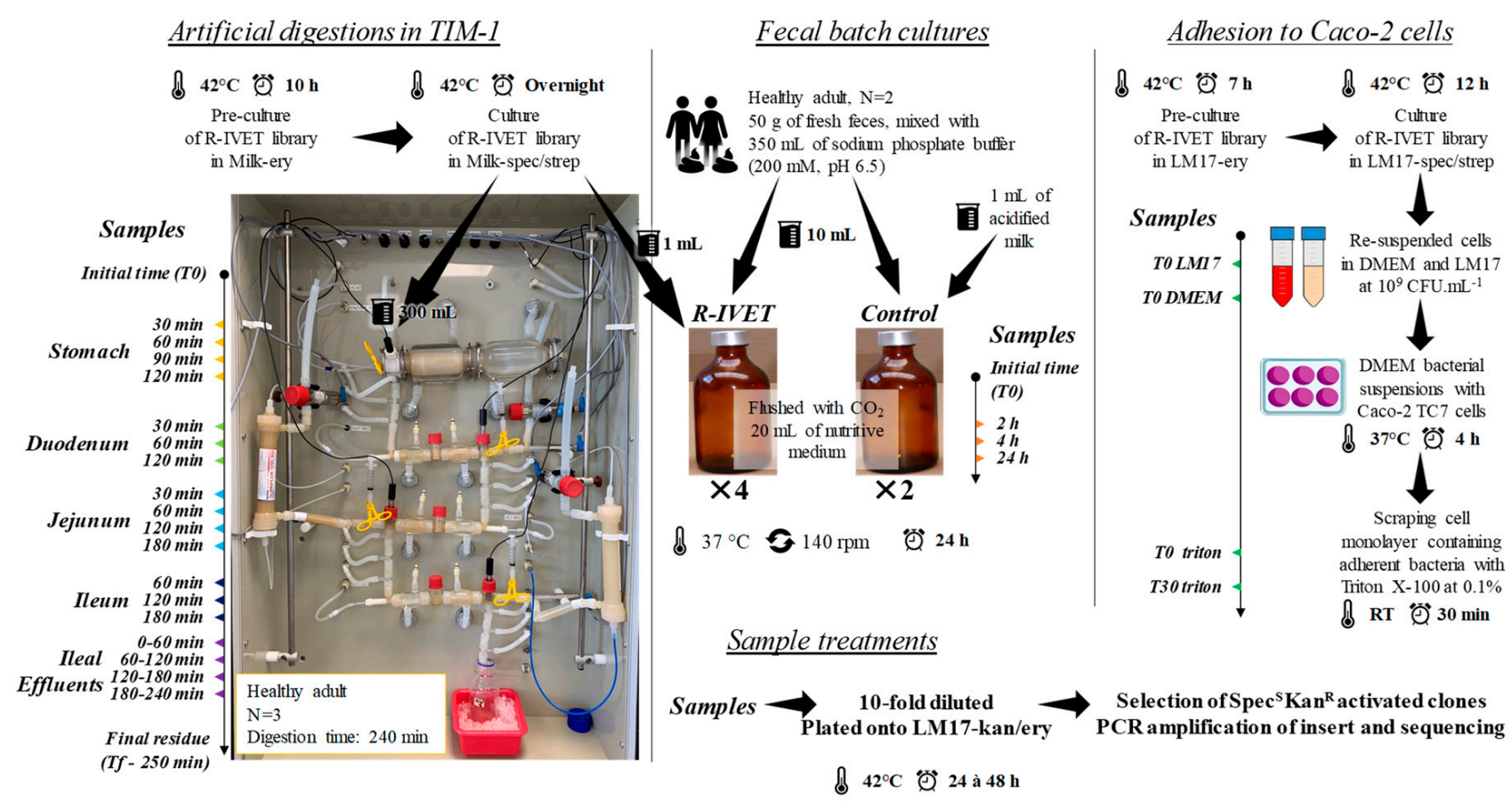

Figure 2. Overview of R-IVET experiments in the three complementary human gut models.

Table 2. Parameters of TIM-1 gastrointestinal model used to simulate milk digestion by a healthy human adult (adapted from [18]).

\begin{tabular}{|c|c|c|c|c|c|}
\hline Compartment & $\begin{array}{l}\text { Volume }(\mathrm{mL}) \\
\text { at Initial Time }\end{array}$ & pH/Time (min) & Digestive Secretions & $\begin{array}{c}t_{1 / 2} \\
(\mathrm{~min})\end{array}$ & $\begin{array}{c}\beta \text { Coeffi- } \\
\text { cient }\end{array}$ \\
\hline Stomach & 310 & $\begin{array}{c}2 / 0,4.2 / 20,2.8 / 40 \\
2.1 / 60,1.8 / 90 \\
1.7 / 120,1.7 / 240\end{array}$ & $\begin{array}{c}0.25 \mathrm{~mL} / \mathrm{min} \text { of pepsin }(500 \mathrm{U} / \mathrm{mL}) \\
0.25 \mathrm{~mL} / \mathrm{min} \text { lipase }(75 \mathrm{U} / \mathrm{mL}) \text { or } \mathrm{HCl}(3 \mathrm{M}) \text { if } \\
\text { necessary }\end{array}$ & 30 & 1 \\
\hline Duodenum & 40 & Maintained at 6.0 & $\begin{array}{c}0.5 \mathrm{~mL} / \mathrm{min} \text { of bile porcine extract }(4 \% w / w \text { during } \\
\text { the first } 30 \text { min of digestion and then } 2 \% w / w) \\
0.25 \mathrm{~mL} / \mathrm{min} \text { of porcine pancreatin }(14.1 \% w / w) \\
0.25 \mathrm{~mL} / \mathrm{min} \text { of intestinal electrolyte solution or } \\
\mathrm{NaHCO}_{3}(1 \mathrm{M}) \text { if necessary }\end{array}$ & & \\
\hline Jejunum & 105 & Maintained at 6.8 & $0.25 \mathrm{~mL} / \mathrm{min}$ of $\mathrm{NaHCO}_{3}(1 \mathrm{M})$ if necessary & & \\
\hline Ileum & 110 & Maintained at 7.2 & $0.25 \mathrm{~mL} / \mathrm{min}$ of $\mathrm{NaHCO}_{3}(1 \mathrm{M})$ if necessary & 160 & 1.6 \\
\hline
\end{tabular}

A power exponential equation $\left(f=1-2^{-(t / t 1 / 2) \beta}\right.$ where $f$ represents the fraction of meal delivered, $t$ is the time of delivery, $t_{1 / 2}$ is the half-time of delivery, and $\beta$ is a coefficient describing the shape of the curve) was used for the computer control of gastric and ileal deliveries.

R-IVET library clones were precultured for $10 \mathrm{~h}$ in milk supplemented with erythromycin. Then, the library was cultured overnight in $300 \mathrm{~mL}$ of milk supplemented with spectinomycin and streptomycin. Before introduction into the TIM-1 stomach, the fermented milk was homogenized by vortexing at room temperature for $5 \mathrm{~min}$. Samples $(1 \mathrm{~mL})$ were collected from the initial fermented milk (T0) and at several time points during in vitro digestion in the stomach $(30,60,90$, and $120 \mathrm{~min})$, duodenum $(30,60$, and $120 \mathrm{~min})$, jejunum $(30,60,120$, and $180 \mathrm{~min})$, and ileum $(60,120$, and $180 \mathrm{~min})$. Ileal effluents were also kept on ice and collected as pools of periods covering 0-60, 60-120, 120-180, and $180-240 \mathrm{~min}$. At the end of digestion, the gastrointestinal residue was recovered. Samples were 10-fold diluted and appropriate dilutions were plated on LM17 agar (viable count) and on LM17 agar supplemented with a mix of kanamycin and erythromycin (selection of activated $\mathrm{Spec}^{\mathrm{S}} \mathrm{Kan}^{\mathrm{R}}$ clones). Three independent experiments were performed in the TIM-1 system. 


\subsection{Fecal Batch Cultures}

Fresh feces from healthy human volunteers were used to prepare the bacterial inoculum for batch cultures. Stools ( $50 \mathrm{~g})$ were mixed with $350 \mathrm{~mL}$ of sodium phosphate buffer (200 mM, pH 6.5) and filtered through a double layer of gauze under strictly anaerobic conditions in a vinyl anaerobic chamber (Coy, Grass Lake, MI, USA). Ten milliliters of the fecal suspension was rapidly transferred to $50 \mathrm{~mL}$ crimped vials, flushed with $\mathrm{CO}_{2}$, and filled with $20 \mathrm{~mL}$ of nutritive medium (Figure 2). The nutritive medium contained various carbohydrate, protein, lipid, mineral, and vitamin sources, as previously described by Thévenot et al. [38]. For each fecal sample, six vials were prepared and sealed: two control vials with $1 \mathrm{~mL}$ of acidified milk and four vials containing $1 \mathrm{~mL}$ of an R-IVET genomic library culture. The vials were incubated for $24 \mathrm{~h}\left(37^{\circ} \mathrm{C}, 140 \mathrm{rpm}\right)$, and samples $(1 \mathrm{~mL})$ were collected at $0,2,4$, and $24 \mathrm{~h}$. Appropriate dilutions were plated on LM17 agar supplemented with a mix of spectinomycin and streptomycin (viable count) and on the same medium supplemented with a mix of kanamycin and erythromycin (selection of $\mathrm{Spec}^{\mathrm{S}} \mathrm{Kan}^{\mathrm{R}}$ activated clones and plasmid presence through erythromycin resistance). The experiments were performed in duplicate with the feces of two adult volunteers, a male and a female.

\subsection{In Vitro Adhesion to Caco-2 Cultures}

The R-IVET library was precultured overnight in LM17 supplemented with erythromycin and cultured for $12 \mathrm{~h}$ in LM17 supplemented with spectinomycin and streptomycin. The Caco-2 TC7 cell line was used for adhesion studies, and cell culture experiments were performed as previously described by Kebouchi et al. [16] with some modifications. Briefly, bacterial cells from $12 \mathrm{~h}$ cultures were pelleted, washed, and resuspended at a final concentration of $10^{9} \mathrm{CFU} / \mathrm{mL}$ (OD $650 \mathrm{~nm}$ of about 12) in Dulbecco's modified Eagle's Minimal Essential Medium (DMEM) with $4.5 \mathrm{~g} / \mathrm{L}$ glucose (DMEM Glutamax, Fisher Scientific) or in LM17, used as a control. Subsequently, samples were taken separately from the two bacterial suspensions corresponding to T0 LM17 and T0 DMEM samples (Figure 2). Afterward, the bacterial suspension in DMEM was added to a confluent Caco-2 TC7 cell monolayer at a final concentration of $10^{9} \mathrm{CFU} / \mathrm{mL}$ to reach a bacterial-cell-toepithelial-cell ratio of 1000:1. Bacterial cells were co-incubated with the cell monolayer for $4 \mathrm{~h}$ at $37^{\circ} \mathrm{C}$ in a humidified atmosphere with $10 \% \mathrm{CO}_{2}$ and processed further according to Kebouchi et al. [16] to recover cells. All cells (adherent bacteria and eukaryotic cells) recovered from two inserts were pooled and then incubated $30 \mathrm{~min}$ at room temperature. Samples were taken separately after recovering from triton treatment of bacterial suspension (T0 triton) and after 30 min incubation (T30 triton). Serial dilutions of all samples (T0 LM17, T0 DMEM, T0 triton, and T30 triton) were performed, and appropriate dilutions were plated onto LM17 agar supplemented with either a mix of spectinomycin and streptomycin or a mix of kanamycin and erythromycin (selection of activated $\mathrm{Spec}^{\mathrm{S}} \mathrm{Kan}^{\mathrm{R}}$ clones having a recombinant plasmid). Plates were then incubated at $42{ }^{\circ} \mathrm{C}$ for $48 \mathrm{~h}$. Three independent R-IVET adhesion experiments were conducted with Caco-2 TC7 cells. 


\subsection{Sequence Analyses}

In the three gut models, excision of the chromosomal cassette was firstly checked in $\mathrm{Spec}^{\mathrm{S}} \mathrm{Kan}^{\mathrm{R}}$ clones (qualified as an activated R-IVET clone) by PCR using the primer pair \#22 and \#29 (Table S1, Supplementary Materials). Detection of a $628 \mathrm{bp}$ amplicon confirmed that the loxP-specR fragment of the R-IVET cassette was deleted because of promoter induction in the recombinant plasmid. To determine which genes from $S$. thermophilus were induced, the plasmid insert of each activated R-IVET clone was amplified using primers \#18 and \#19, purified, and sequenced using the same primers by Genewiz Company (Takeley, UK). The nucleotide sequences were analyzed by NCBI BLASTn using the annotated genome sequence of wild-type $S$. thermophilus LMD-9 [34]. A promoter prediction was performed on sequences obtained by using the online promoter prediction tools Softberry BPROM [39] and phiSITE Promoter Hunter [40].

\subsection{Statistical Analyses}

Data were analyzed using a two-way repeated-measures analysis of variance (ANOVA) followed by a Bonferroni test. The statistical analyses were performed using GraphPad Prism software 7.01 (GraphPad Software, Inc., San Diego, CA, USA). Results were expressed as means \pm SEM. Differences were considered statistically significant when $p<0.05$. Survival kinetics of the R-IVET library in the TIM-1 system were compared to that of a theoretical transit marker provided by the computer. This marker evolves according to the volume of each compartment, the rate of dilution by digestive secretions, and the chyme flow between two successive compartments, and it corresponds to a $100 \%$ survival rate. The comparison was independently performed in each compartment and at each time of sampling. For fecal batch cultures, the number of cultivable cells was determined, and a comparison was independently performed between volunteer 1 and 2 at each time of sampling.

\section{Results}

\subsection{Construction and Validation of the R-IVET Positive Screening Tool}

The R-IVET positive screen was designed on the basis of the strategy developed for Enterococcus faecalis [40]. The chromosomal cassette consisting of two antibiotic resistance genes was constructed as detailed in Figure 1 and in Section 2.3 and then introduced into the locus STER_0891, encoding a putative glucose uptake permease, of the $S$. thermophilus LMD9 genome to obtain the mutant strain STUL5003. This cassette consisted of the promoter (prom) of the kanamycin resistance gene kan $R$, followed by a loxP site, the spectinomycin resistance gene specR with its own promoter, the Tlas terminator, another loxP site, and the promoterless kanR gene. Thus, the strain STUL5003 was resistant to spectinomycin and sensitive to kanamycin (phenotype $\operatorname{Spec}^{\mathrm{R}} \mathrm{Kan}^{\mathrm{S}}$ ). It was expected that, under the expression of the Cre recombinase, the specR gene would be excised and, consequently, the kanR would be correctly positioned to be expressed under the promoter prom (Figure 3).

The STUL5003 chromosomal cassette was sequenced to ensure that no mutation occurred during the construction. When compared with the expected sequence of the R-IVET cassette, two mutations were detected: replacement of a cytosine by a guanine in the prom region and deletion of a cytosine in the transcription terminator of the spec $R$ gene. Regarding the position of these mutations, as well as the phenotype of STUL5003 and STUL5003-plac strain colonies, as presented below, we concluded that these mutations had no significant impact on the functionality of our R-IVET tool. 
A)

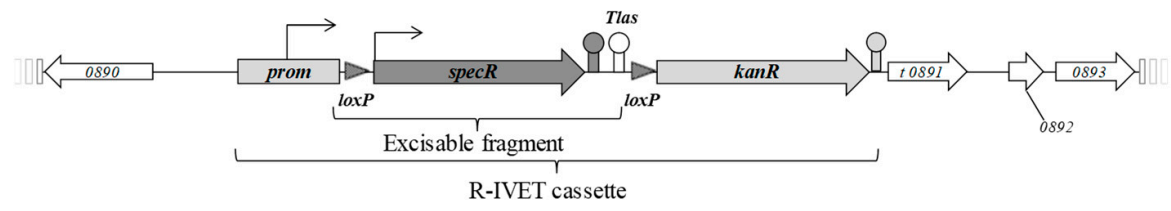

B)

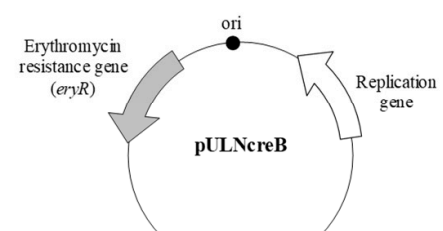

C) No promoter
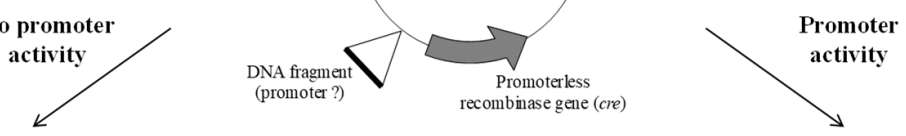

D)
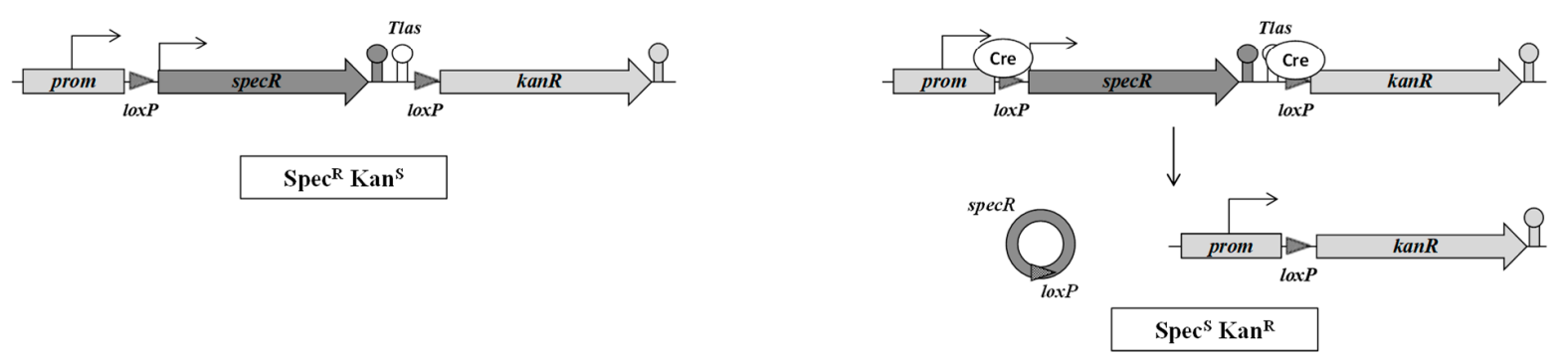

Figure 3. Schematic representation of positive-selection R-IVET screen in S. thermophilus STUL5003. The R-IVET technology consists of two elements. The first one is the chromosomal cassette (A) with the spectinomycin resistance gene (specR) flanked by two loxP sites followed by the promoterless kanamycin resistance gene (kanR). The second element is the pULNcreB plasmid (B, Table 1) which possesses the promoterless recombinase gene (cre). Cre recombinase recognizes the loxP sites of the cassette. (C) When the DNA fragment cloned upstream of the cre gene is without promoter activity, only the specR gene is expressed and the two terminators, i.e., specR gene and Tlas downstream of the specR gene, prevent expression of the kanR gene. The corresponding clone is spectinomycin-resistant and kanamycin-sensitive (Spec $\left.{ }^{R} \mathrm{Kan}^{\mathrm{S}}\right)$. (D) When the DNA fragment possesses promoter activity, Cre recombinase is produced and leads to excision of the specR gene; the kanR gene can, therefore, be expressed from its own promoter. Hence, the clone is spectinomycin-sensitive and kanamycin-resistant $\left(\operatorname{Spec}^{\mathrm{S}} \mathrm{Kan}^{\mathrm{R}}\right)$.

Functionality of the R-IVET positive screen was validated using the plasmid pULNcreBplac containing the plac promoter of lactose operon (Table 1). As this promoter is inducible by lactose and less active in the presence of glucose [23], it was expected that, following the expression of Cre recombinase, all STUL5003-plac strain colonies grown in the presence of lactose would lose the specR gene and express the kanR gene. Hence, this plasmid was introduced into STUL5003 strain to obtain STUL5003-plac strain. Sixty randomly chosen colonies from both strains were grown on five different agar media to check their antibiotic resistance phenotype: LM17 medium without antibiotic (control) or supplemented with either spectinomycin or erythromycin (to confirm the presence of pULNcreB-plac plasmid, which has the ermE gene conferring erythromycin resistance), with kanamycin, or with a mix of erythromycin and kanamycin. We observed that all 60 STUL5003-plac strain colonies exhibited a Spec ${ }^{S} \operatorname{Kan}^{\mathrm{R}}$ Ery $^{\mathrm{R}}$ phenotype, because they grew without antibiotic, as well as with erythromycin, kanamycin, or both, but not with spectinomycin. As expected, none of the 60 STUL5003 strain colonies was able to grow with erythromycin and/or kanamycin, while they grew with spectinomycin, as well as on control medium $\left(\mathrm{Spec}^{\mathrm{R}} \mathrm{Kan}^{\mathrm{S}} \mathrm{Ery}^{\mathrm{S}}\right.$ phenotype). The presence/absence of a loxP-specR excisable fragment was checked by PCR in randomly chosen colonies of STUL5003 and STUL5003-plac strains. In each colony (6/6) of STUL5003 strain, an amplicon of $2091 \mathrm{bp}$ was observed as expected since loxP-specR was present, while an amplicon of 628 bp was detected in each colony (3/3) of STUL5003-plac strain, since loxP-specR was absent. Lastly, sequencing of three STUL5003-plac amplicons confirmed that the chromosomal cassette was deleted. 
In addition to validation of R-IVET positive screening, these results also attested to a certain stability of the chromosomal cassette, since none of the 60 STUL5003 colonies lost the chromosomal cassette through a recombination between the loxP sites which, in fact, constituted direct repeats. Lastly, it must be underlined that, at this stage, all of the Spec $^{\mathrm{S}} \operatorname{Kan}^{\mathrm{R}}$ Ery $^{\mathrm{R}}$ R-IVET clones (almost 2500) analyzed throughout this work displayed a recombinant pULNcreB.

\subsection{Construction of the R-IVET Genomic Library and Counterselection of Activated R-IVET Clones}

The R-IVET genomic library was constructed using Escherichia coli TOP10 as an intermediate cloning host. Genomic DNA of S. thermophilus LMD-9 partially digested with AluI was ligated with SmaI-digested pULCreB plasmid (Table 1). Then, recombinant plasmids were introduced into E. coli TOP10, and 72,000 clones were selected. Plasmids extracted from E. coli TOP10 were introduced into $S$. thermophilus STUL5003, resulting in approximately 114,600 colonies selected on LM17-ery medium. Hence, PCRs were performed on plasmids from 56 randomly chosen R-IVET recombinant clones to (i) assess the proportion of recombinant clones, and (ii) establish insert sequences to evaluate LMD-9 genome recovery. The results showed that 37.5\% (21/56) of R-IVET clones possessed an insert, with an average size of $500 \mathrm{bp}$. Analyses of insert sequences revealed that 13 corresponded to simple inserts and eight corresponded to multi-inserts. In the rest of this work, about $50 \%$ of R-IVET activated clones exhibited a multi-insert. They were systematically excluded from analyzes. This probably resulted from the method used to set-up the R-IVET genomic library, since it was decided to dephosphorylate the SmaI-digested pULNcreB vector to avoid its self-ligation instead of dephosphorylating the inserts. According to the proportion of recombinant clones (37.5\%) and of that of multi-inserts (50\%), the probability that each part of $S$. thermophilus LMD-9 genome exists at least once in the form of a simple insert was estimated at 0.997, using the Clarke and Carbon formula [41]. Lastly, the corresponding fragments of simple inserts came from different parts of the $S$. thermophilus genome, and no specific genomic region appeared to be over- or under-represented.

As R-IVET technology was used to identify promoters specifically induced under simulated human digestive conditions, counterselection of R-IVET recombinant clones containing a promoter induced during their growth before introduction into one of the three gut models used in this work constituted an essential first step. Hence, preselection conditions were optimized to eliminate $\mathrm{Spec}^{\mathrm{S}} \mathrm{Kan}^{\mathrm{R}}$ clones (i.e., clones where recombinase was expressed) and select $\mathrm{Spec}^{\mathrm{R}} \mathrm{Kan}^{\mathrm{S}}$ clones (i.e., clones keeping an intact original chromosomal cassette since Cre recombinase was not expressed). R-IVET genomic library clones were grown either in milk (growth medium used for the TIM-1 system and batch cultures of human fecal microbiota) or in LM17 (Caco-2 TC7 model) and exposed to antibiotics at different times, as described in Section 2.5. The better selection condition found corresponded to exposition for at least $7 \mathrm{~h}$ to a mix of spectinomycin/streptomycin (specR conferring resistance to both antibiotics) but it seemed impossible to eliminate $\operatorname{Spec}^{\mathrm{S}} \mathrm{Kan}^{\mathrm{R}}$ clones present in initial cultures. Consequently, the $\mathrm{Kan}^{\mathrm{R}}$ clones obtained at the beginning of each experiments (T0) were systematically and carefully analyzed in each of the experiments described in this work.

\subsection{Survival Kinetics of S. thermophilus under Human Simulated Conditions}

Before starting selection of activated R-IVET clones in the three complementary gut models, viability of the R-IVET genomic library under digestive conditions was established, given that $S$. thermophilus survival in the human GI tract is a key parameter to consider for further evaluation as a probiotic, according to the regulatory definition [6]. Fermented milk was chosen as a food carrier for S. thermophilus in TIM-1 and in fecal batch cultures, since it was previously shown to improve bacterial survival in the in vitro stomach compared to milk [18]. Furthermore, S. thermophilus is commonly consumed by humans via ingestion of fermented milks such as yogurt. For the Caco-2 TC7 adhesion model, a culture medium simpler than fermented milk, i.e., LM17 medium was preferred. 
In TIM-1, bacterial survival kinetics was not significantly different from that of a theoretical transit marker provided by the in vitro model during the 60 min digestion in the gastric compartment (Figure 4A). Conversely, significant bacterial mortality $(p<0.0001)$ was observed from $90 \mathrm{~min}$ when $\mathrm{pH}$ fell below 1.8, with a loss of $3 \log _{10} \mathrm{CFU}$ and $7 \log _{10}$ CFU compared to the transit marker at 90 and $120 \mathrm{~min}$, respectively. Monitoring of R-IVET library cell numbers in the three compartments of the small intestine showed a negative impact of digestive conditions on survival ability of these clones in post-gastric conditions (Figure 4A). The number of viable cells showed a significant decrease $(p<0.001)$ in the small intestinal compartments after $120 \mathrm{~min}$ of digestion, with a loss of around $8 \log _{10}$ $\mathrm{CFU}$ in the duodenum and $6 \log _{10} \mathrm{CFU}$ in the jejunum and ileum compared to the transit marker. Bacterial cells which survived the whole digestive process were recovered in the TIM-1 ileal effluents. Final counts, i.e., when the numbers of bacterial cells in ileal effluents and gastrointestinal residue were added, reached $8.2 \log _{10} \mathrm{CFU}$ versus $9.2 \log _{10} \mathrm{CFU}$ for the wild-type strain, as previously established by Uriot et al. [18]. This could result either from interruption of the STER_0891 locus where the chromosomal cassette was introduced or from a mutation elsewhere in the genome of STUL5003 strain.

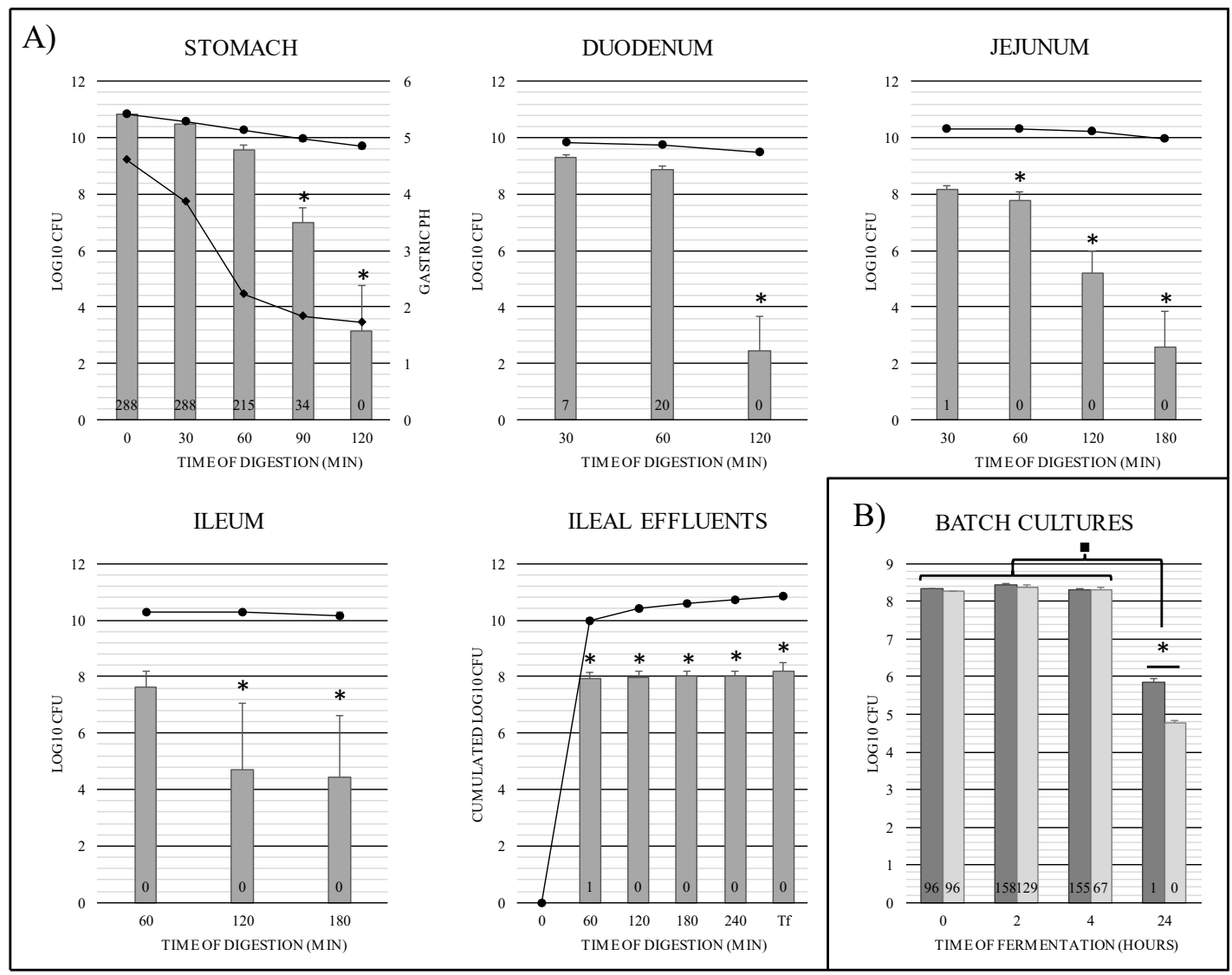

Figure 4. Bacterial survival and number of activated R-IVET clones obtained and analyzed in each TIM-1 compartment (A) and in fecal microbiota batch cultures (B). (A) In each TIM-1 compartment, data points obtained for the R-IVET library and the theoretical transit marker are represented by gray bars and black circle curves, respectively. In the stomach compartment, the black diamond curve gives the gastric $\mathrm{pH}$ evolution over time. Tf represents the cumulated ileal effluents plus gastrointestinal residue collected at the end of TIM- 1 experiment. Values are given as means of $\log _{10}$ CFU \pm SEM ( $n=3$ ). At each time, results for the R-IVET library were compared to those of the transit marker. Significant differences are noted by asterisks (ANOVA and Bonferroni test, $p<0.05$ ). Numbers in bars correspond to the total number of activated R-IVET clones obtained and analyzed at each time point. (B) For batch cultures, dark-gray bars and light-gray bars represent data from volunteer 1 (man) and volunteer 2 (woman), respectively. Values are given as means of $\log _{10} \mathrm{CFU} \pm \mathrm{SEM}$ (four technical replicates). Values at each time point were compared to those obtained at $\mathrm{T}_{0}(\boldsymbol{\square}<0.05)$ and between each volunteer $\left({ }^{*} p<0.05\right)$. Numbers in bars correspond to the total number of activated R-IVET clones analyzed at each time point. 
In batch cultures of human fecal microbiota, survival rates of the R-IVET library remained unchanged during the first $4 \mathrm{~h}$ of incubation (Figure 4B), and no significant difference was observed between the two volunteers. However, after $24 \mathrm{~h}$ incubation, the number of viable $S$. thermophilus R-IVET cells significantly decreased by approximately 2.5 and $3.5 \log _{10}$ CFU for volunteers 1 and 2, respectively. The final survival rate was significantly different $(p<0.0001)$ between the two volunteers. This result suggested that the R-IVET library was not able to colonize the colon, as observed with wild-type strains in animals and humans after yogurt ingestion [17]. In previous studies in germ-free rat models, lactose was shown to significantly improve the survival capacity of $S$. thermophilus in the GI tract [21,42]. Of note, here, no supplementary nutrient or carbon source that could have been easily used by $S$. thermophilus was added to batch cultures.

Lastly, the survival ability of the R-IVET library was determined in the medium used for Caco-2 TC7 cell adhesion assays, in the same conditions as described in Figure 2, but without Caco- 2 cells. Results showed no significant decrease in clone survival after $4 \mathrm{~h}$ incubation in DMEM medium and triton X-100 at 0.1\% (Figure S1, Supplementary Materials).

\subsection{Sequence Analyses of Initially Activated (T0) R-IVET Genomic Library Clones}

For the reasons exposed before, R-IVET clones displaying a Spec ${ }^{S} \mathrm{Kan}^{\mathrm{R}}$ phenotype at T0, i.e., before their introduction in one of the three models, were selected and analyzed. From a physiological point of view, they corresponded to clones that were in a stationary growth phase, with a growth medium at about $\mathrm{pH}$ 4.6. Sequencing of inserts from a total of 963 clones selected revealed that about $50 \%$ consisted of multiple inserts, which were eliminated from the study. Sequencing of single inserts revealed that they originated from about 150 different genes, with certain inserts matching with at least two genes because of the presence of repeated sequences inside the inserts (Table S2, Supplementary Materials). This implies that most of the 150 genes were observed several times. Three situations were distinguished, whereby inserts included (i) a gene promoter (84 genes or $56 \%$ ), (ii) a sequence located inside the promoter of a gene but on the antisense strand (eight genes or $0.05 \%$ ), and (iii) a sequence located inside a gene, on either the sense or the antisense strand (Figure 5 and Table S2, Supplementary Materials). Interestingly, among the 49 promoters from T0 clones of TIM- 1 and fecal batch culture, 33 were identified in both and probably correspond to genes induced during growth in milk. Lastly, $20 \mathrm{T0}$ clones were common to the three gut models, which is consistent with them corresponding to genes involved in basic cellular functions, for example, PepS aminopeptidase, subunit III of DNA polymerase III, ATP subunit of Clp protease, DNA/RNA helicase, or DNA polymerase I (Table S2, Supplementary Materials).

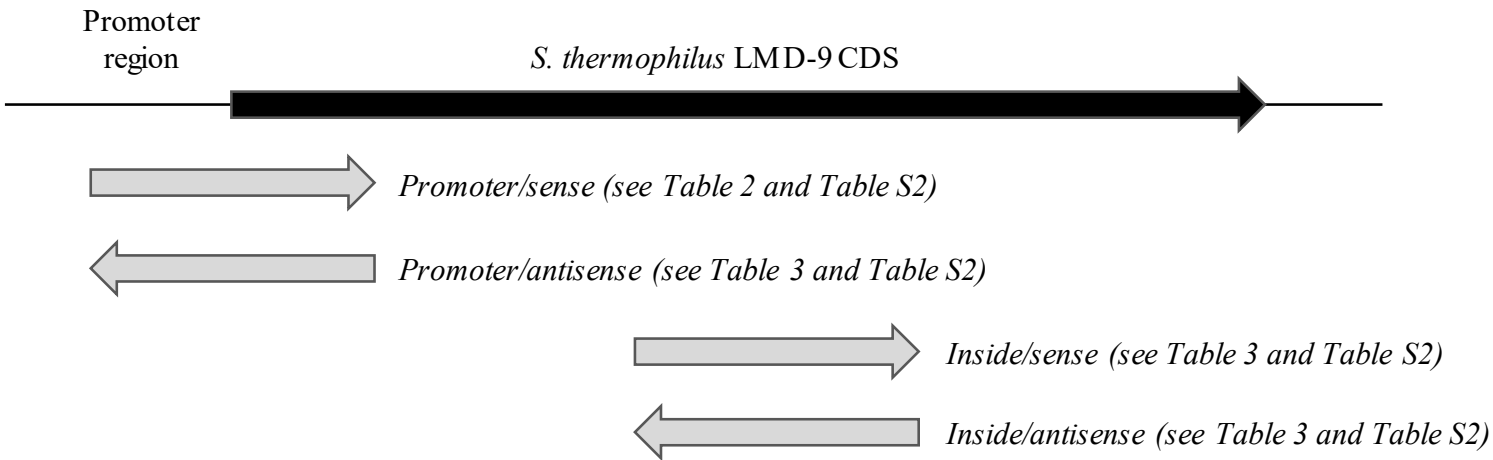

Figure 5. Location, orientation, and denomination of inserts of activated R-IVET clones compared to S. thermophilus LMD-9 genes. CDS: coding DNA sequence. 


\subsection{Identification of S. thermophilus Functions Induced in GI Models}

After transit through TIM-1, fecal batch incubation, or adhesion to Caco-2 TC7 cells, $1461 \mathrm{Spec}^{\mathrm{S}} \mathrm{Kan}^{\mathrm{R}}$ clones were recovered for further analysis. As for T0 samples, single or multiple inserts upstream of cre gene were observed. Once multiple inserts and T0 activated genes were excluded from the analysis, the resting single-insert sequence corresponded to 98 genes. Once again, some of them were found several times. For 44 genes, the insert included the promoter of a gene already annotated on the LMD-9 strain genome (Table 3), whereas the insert corresponding to the 54 other genes included an internal gene sequence (on the sense or antisense strand) or sequences located on the antisense strand of a gene promoter region (Table 4). Analysis of their sequences using promoter prediction software showed that all of them contained at least a strong signal of promoter activity, often well positioned in relation to the gene $\mathrm{cre}$, considering that $45 \mathrm{bp}$ separated the end of the insert from the beginning of gene cre.

Of the 44 gene promoters, 18, 20, and six were identified in TIM-1, Caco-2 TC7 cells, and fecal batch cultures, respectively (Table 3). In TIM-1, the 18 promoters were identified in the stomach compartment, mainly after 30 and 60 min digestion. In fecal batch cultures, two promoters were observed after $2 \mathrm{~h}$ and four promoters were observed after $4 \mathrm{~h}$ incubation. Interestingly, only one promoter was detected both in TIM- 1 and in fecal batch cultures, while others remained gut region-specific. Functional classes of activated genes were also mainly gut model-dependent. For example, seven out of 18 genes activated in TIM-1 have a protein synthesis function and three are involved in nutrient absorption and metabolism. In Caco-2 TC7, three genes encoding cell surface proteins and two encoding competence proteins were specifically activated. Lastly, two out of six genes activated in fecal batch cultures are involved in the stress response. Of note, a few genes encoding regulators (two in TIM-1 and one in Caco-2 TC7) were also detected in R-IVET activated clones. Furthermore, four genes encoding hypothetical proteins were activated in Caco-2 TC7 compared to three in TIM-1 and only one in fecal batch cultures. Interestingly, inserts from activated R-IVET library clones located inside genes or on the antisense strand mainly belonged to genes involved in nutrient absorption and metabolism $(15 / 55)$, protein synthesis (5/55), and stress response (6/55). On the remaining 23 inserts, 13 belonged to genes involved in various functions such as peptide synthesis, DNA repair, or DNA internalization (Table 4). 
Table 3. Inserts from activated R-IVET library clones identified under simulated human digestive conditions and found in the annotated S. thermophilus LMD-9 genome.

\begin{tabular}{|c|c|c|c|c|c|c|}
\hline Class & $\begin{array}{l}\text { Locus } \\
\text { STER_a } \\
\text { (STER_RS) b }^{\text {bTER }}\end{array}$ & Gene Description & $\begin{array}{l}\text { Position of the Insert } \\
\text { on LMD-9 Genome (nt) }\end{array}$ & TIM-1 & Caco-2 TC7 & $\begin{array}{l}\text { Fecal Batch } \\
\text { Cultures }\end{array}$ \\
\hline \multirow{3}{*}{ Cell surface proteins } & $0314(01525)$ & Membrane protein (predicted) & $270,262-270,470$ & & & \\
\hline & $0758(03720)$ & Membrane protein (predicted) & $690,246-690,721$ & & & \\
\hline & $1197 / 1196 *(05905 / 05900)$ & $\begin{array}{l}\text { Rod shape-determining protein RodA/IS5 family } \\
\text { transposase }\end{array}$ & $1,106,940-1,104,772$ & & & \\
\hline \multirow{2}{*}{ Competence proteins } & $0406(01985)$ & Competence protein & $355,852-357,052$ & & & \\
\hline & $1477(07260)$ & Type II CRISPR RNA-guided endonuclease Cas9 & $1,384,541-1,380,985$ & & & \\
\hline \multirow{5}{*}{$\begin{array}{l}\text { Nutrient absorption and } \\
\text { metabolism }\end{array}$} & $0498 / 0499(02445 / 02450) *$ & Predicted amidohydrolase/transaminase & $445,501-447,041$ & S30 S90 & & \\
\hline & $0949(04695)$ & Zn-dependant alcohol dehydrogenase & $879,316-879,396$ & S30 & & \\
\hline & $1371(06720)$ & Galactokinase & $1,281,820-1,280,237$ & & & \\
\hline & $1494(07350)$ & $\mathrm{ABC}$ transporter permease & $1,399,529-1,399,241$ & & & \\
\hline & $1743(08515)$ & Branched-chain amino-acid transporter & $1,633,154-1,633,062$ & & & \\
\hline \multirow{7}{*}{ Protein biosynthesis } & $0208(01025)$ & 30S ribosomal protein S15 & $176,108-176,450$ & S30 S60 & & \\
\hline & r0082/t0083 (00415/00420) & & $71,512-71,726$ & & & \\
\hline & r0071/t0072 (00830/00835) & 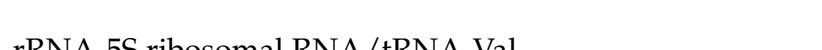 & $145,721-145,935$ & & & \\
\hline & r0184/t0185 (00895/00900) & & $151,527-151,756$ & & & \\
\hline & r1781/t1780 (08710/08705) & rRNA-bS ribosomal RNA/tRNA-Asn & $1,662,586-1,662,357$ & S30 & & \\
\hline & $1726(08440)$ & 30 S ribosomal protein $\mathrm{S} 18$ & $1,616,742-1,616,519$ & & & M4 \\
\hline & $1906 / 1905 *(09340 / 09335)$ & $50 S$ ribosomal protein $\mathrm{L} 4$ & $1,768,760-1,767,556$ & & & M4 \\
\hline \multirow{3}{*}{ Regulators } & $0583 / 0582 *(02870 / 02865)$ & $\begin{array}{l}\text { DNA-binding response regulator/Predicted signal } \\
\text { transduction protein with C-terminal HATPase domain }\end{array}$ & $531,843-530,986$ & & & \\
\hline & $0901(04465)$ & LysR family transcriptional regulator & $833,783-832,546$ & S30 & & \\
\hline & $1693(08275)$ & $\begin{array}{l}\text { Trancriptional regulator (helix-turn-helix XRE-family like } \\
\text { protein) }\end{array}$ & $1,582,297-1,583,056$ & S30 S60 & & \\
\hline \multirow{4}{*}{ Stress response } & B1 (09830) & Acid-shock protein (Hsp20) & $1282-301$ & & & \\
\hline & $0303(01470)$ & Noncanonical purine NTP pyrophosphatase & $261,471-261,718$ & S30 & & \\
\hline & $0572(02820)$ & $\mathrm{ABC}$ permease transporter & $517,756-517,057$ & & & W2 \\
\hline & $1347(06650)$ & $\mathrm{ABC}$ permease transporter & $1,253,799-1,254,182$ & & & W2 \\
\hline
\end{tabular}


Table 3. Cont.

\begin{tabular}{|c|c|c|c|c|c|c|}
\hline Class & $\begin{array}{l}\text { Locus } \\
\text { STER_a }^{a} \\
\text { (STER_RS) }^{b}\end{array}$ & Gene Description & $\begin{array}{l}\text { Position of the Insert } \\
\text { on LMD-9 Genome (nt) }\end{array}$ & TIM-1 & Caco-2 TC7 & $\begin{array}{l}\text { Fecal Batch } \\
\text { Cultures }\end{array}$ \\
\hline \multirow{6}{*}{ Hypothetical proteins } & $0004(00020)$ & Hypothetical protein & $3416-4150$ & & & \\
\hline & 0711/0712 (03500/03505) & $\begin{array}{l}\text { CRISPR-associated protein, Cas } 2 \text { family/hypothetical } \\
\text { protein }\end{array}$ & $647,294-648,230$ & & & \\
\hline & $0807(03965)$ & Hypothetical protein & $741,250-739,908$ & & & \\
\hline & $\begin{array}{l}1048 / 1047 / 1046 * \\
(05200 / 05195 / 05190)\end{array}$ & $\begin{array}{l}\text { Hypothetical protein (phasin protein } \\
\text { superfamily)/predicted unusual protein } \\
\text { kinase/hypothetical protein }\end{array}$ & $974,176-971,354$ & $\mathrm{~S} 30$ & & W4 \\
\hline & $1319(06515)$ & Hypothetical protein (nitroreductase-like protein family) & $1,228,286-1,227,463$ & S30 S60 & & \\
\hline & $1968(09625)$ & Hypothetical protein & $1,818,680-1,819,008$ & & & \\
\hline \multirow{9}{*}{$\begin{array}{l}\text { Other functions } \\
\text { and pseudogenes }\end{array}$} & $0574(02830)$ & Pseudo, partial start: fibronectin-binding protein & $518,245-518,397$ & & & \\
\hline & $0811(03990)$ & Transposase & $746,827-746,519$ & & & \\
\hline & $0972(04800)$ & CRISPR-associated endoribonuclease Cas6 & $897,070-898,203$ & & & M4 \\
\hline & $1074(05335)$ & Pseudogene: voltage-gated chloride channel & $998,385-997,070$ & & & \\
\hline & $1357 / 1356 *(10575 / 06690)$ & $\begin{array}{l}\text { Hypothetical protein } / \mathrm{KxxxW} \text { cyclic peptide radical SAM } \\
\text { maturase }\end{array}$ & $1,261,748-1,260,668$ & S60 & & \\
\hline & $1485(07300)$ & Arsenate reductase family protein & $1,391,653-1,391,193$ & & & \\
\hline & $1824(08910)$ & tRNA-binding protein & $1,701,896-1,701,414$ & S60 & & \\
\hline & $1859(09090)$ & Pseudogene: alcohol dehydrogenase & $1,740,375-1,739,341$ & & & \\
\hline & 1952 (09545) & $\begin{array}{l}\text { Pseudogene: 5-methyltetrahydrofolate-homocysteine } \\
\text { methyltransferase }\end{array}$ & $1,810,490-1,810,368$ & & & \\
\hline
\end{tabular}

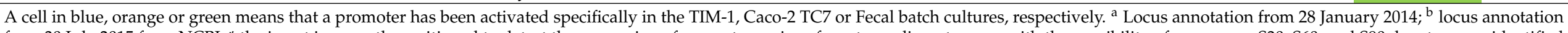

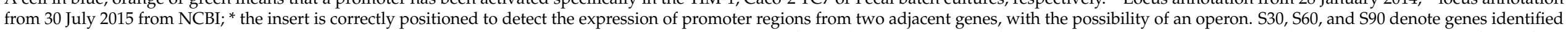

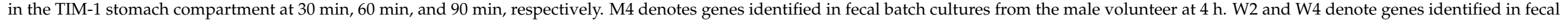
batch cultures from the female volunteer at $2 \mathrm{~h}$ and $4 \mathrm{~h}$, respectively. 


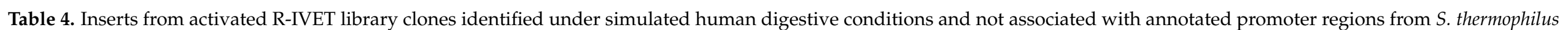
LMD-9 genome.

\begin{tabular}{|c|c|c|c|c|c|c|c|}
\hline Class & $\begin{array}{l}\text { Locus } \\
\text { STER_a } \\
\text { (STER_RS0) }^{b}\end{array}$ & Gene Description & $\begin{array}{c}\text { Location and } \\
\text { Direction Compared } \\
\text { to the Gene }\end{array}$ & $\begin{array}{l}\text { Position of the } \\
\text { Insert on LMD-9 } \\
\text { Genome (nt) }\end{array}$ & TIM-1 & Caco-2 TC7 & $\begin{array}{l}\text { Fecal Batch } \\
\text { Cultures }\end{array}$ \\
\hline \multirow{15}{*}{$\begin{array}{l}\text { Nutrient absorption } \\
\text { and metabolism }\end{array}$} & $0157(0760)$ & PFL family protein & Inside/sense & $129,819-130,812$ & $\mathrm{~S} 60$ & & \\
\hline & $0391(1905)$ & Cysteine desulfhydrase & Inside/sense & $345,914-346,179$ & & & \\
\hline & $0429(2100)$ & 3-Oxoacyl-ACP synthase III & Promoter/antisense & $374,511-374,069$ & & & \\
\hline & $0445(2180)$ & 1-Phosphofructokinase & Promoter/antisense & $389,930-389,309$ & & & W4 \\
\hline & $0537(2635)$ & N-Acetylglucosamine-6-phosphate deacetylase & Inside/antisense & $483,279-483,109$ & $\mathrm{~S} 60$ & & \\
\hline & $0654(3225)$ & Ferrous iron transport protein $\mathrm{B}$ & Promoter/antisense & $594,581-593,569$ & & & M4 \\
\hline & $0713(3510)$ & Phosphate $\mathrm{ABC}$ transporter substrate-binding protein & Inside/sense & $651,008-650,690$ & & & \\
\hline & $1009(4970)$ & $\begin{array}{l}\text { ABC-type phosphate transport system, permease } \\
\text { component }\end{array}$ & Inside/sense & $929,980-930,137$ & & & \\
\hline & $1293(6375)$ & Multidrug ABC transporter ATP-binding protein & Promoter/antisense & $1,201,333-1,202,350$ & & & \\
\hline & $1408(6925)$ & Peptide ABC transporter permease & Inside/sense & $1,316,650-1,316,193$ & $\mathrm{~S} 60$ & & \\
\hline & $1478(7265)$ & Phosphoserine phosphatase SerB & Inside/sense & $1,384,541-1,384,484$ & & & \\
\hline & $1487(7310)$ & 3-Phosphoglycerate dehydrogenase & Inside/sense & $1,392,951-1,392,865$ & S30 & & \\
\hline & $1558(7660)$ & ATPase & Inside/sense & $1,462,899-1,462,760$ & & & \\
\hline & $1566(7700)$ & Dihydroxyacid dehydratase & Inside/antisense & $1,468,250-1,469,229$ & & & \\
\hline & $1793(8770)$ & Glutamate-tRNA ligase & Inside/sense & $\begin{array}{l}1,677,638-1,677,046 \\
1,677,399-1,677,046\end{array}$ & S30 & & \\
\hline \multirow[t]{4}{*}{ Protein biosynthesis } & $0313(1520)$ & $\begin{array}{l}\text { tRNA (uridine(34)/cytosine(34)/5-carboxymethyl } \\
\text { aminomethyluridine(34)-2'-O)-methyltransferase TrmL }\end{array}$ & Inside/sense & $270,267-270,471$ & $\mathrm{~S} 60$ & & \\
\hline & $0368(1785)$ & Serine-tRNA ligase & Inside/sense & $322,147-321,141$ & & & \\
\hline & $0423(2070)$ & $23 S$ rRNA (uracil-5-)-methyltransferase RumA & Inside/sense & $368,157-369,181$ & S30 S60 & & M2 \\
\hline & $0783(3840)$ & Isoleucine-tRNA ligase & Inside/sense & $715,785-716,798$ & & & \\
\hline \multirow{2}{*}{ Regulators } & $0216(1050)$ & Adaptor protein MecA & Promoter/antisense & $182,455-181,444$ & & & \\
\hline & $1965(9615)$ & Pseudogene: PadR family transcriptional regulator & Promoter/antisense & $1,818,077-1,817,746$ & S60 & & \\
\hline \multirow{6}{*}{ Stress response } & $0471(2315)$ & $\mathrm{ABC}$ transporter & Inside/sense & $418,458-419,267$ & & & M4 \\
\hline & $0520(2550)$ & F0F1 ATP synthase subunit gamma & Inside/sense & $467,311-467,205$ & S60 & & \\
\hline & $1293(6375)$ & Multidrug ABC transporter ATP-binding protein & Promoter/antisense & $1,201,333-1,202,350$ & & & \\
\hline & $1348(6655)$ & Peptide ABC transporter ATPase & Inside/antisense & $1,255,962-1,255,041$ & & & \\
\hline & $1444(7105)$ & NAD(P)-dependant oxidoreductase & Inside/antisense & $1,352,291-1,352,194$ & S60 & & \\
\hline & $1470(7230)$ & Peroxiredoxin & Inside/sense & $1,375,130-1,374,976$ & & & W2 \\
\hline
\end{tabular}


Table 4. Cont.

\begin{tabular}{|c|c|c|c|c|c|c|c|}
\hline Class & $\begin{array}{l}\text { Locus } \\
\text { STER_a } \\
\text { (STER_RS0) }^{b}\end{array}$ & Gene Description & $\begin{array}{l}\text { Location and } \\
\text { Direction Compared } \\
\text { to the Gene }\end{array}$ & $\begin{array}{l}\text { Position of the } \\
\text { Insert on LMD-9 } \\
\text { Genome (nt) }\end{array}$ & TIM-1 & Caco-2 TC7 & $\begin{array}{l}\text { Fecal Batch } \\
\text { Cultures }\end{array}$ \\
\hline \multirow{3}{*}{ Hypothetical protein } & $0290(-)$ & Annotation change: no similar match & Promoter/antisense & $253,078-252,966$ & & & \\
\hline & $1642(8055)$ & Hypothetical protein & Inside/sense & $1,534,778-1,534,351$ & S30 S90 & & \\
\hline & $1724(8430)$ & Membrane protein & Inside/sense & $1,614,761-1,614,899$ & & & W2 \\
\hline \multirow{21}{*}{ Other functions } & $0055(0280)$ & Transposase & Inside/antisense & $44,609-43,805$ & & & \\
\hline & $0102(0510)$ & Transposase & Promoter/antisense & $80,702-80,891$ & & & \\
\hline & $0237(1165)$ & Pseudogene & Inside/antisense & $202,301-201,856$ & & & \\
\hline & $0335(1630)$ & Peptide synthetase & Inside/sense & $287,711-288,710$ & & & M2 \\
\hline & $0336(1630)$ & NUDIX family hydrolase & Promoter/antisense & $289,981-289,188$ & S30 & & \\
\hline & $0352(1710)$ & Ribosomal RNA small subunit methyltransferase G & Inside/sense & $308,825-308,525$ & & & \\
\hline & $0378(1835)$ & Transporter & Inside/antisense & $331,510-331,327$ & & & \\
\hline & $0569(2805)$ & \multirow{5}{*}{ ISL3 family transposase } & Promoter/antisense & $513,865-513,496$ & S30 S60 & & \\
\hline & $0631(3095)$ & & Promoter/antisense & $573,221-573,608$ & S30 S60 & & \\
\hline & $0849(4180)$ & & Promoter/antisense & $783,047-783,434$ & S30 S60 & & \\
\hline & $1162(5735)$ & & Promoter/antisense & $1,071,215-1,071,610$ & S30 S60 & & \\
\hline & $1556(7650)$ & & Promoter/antisense & $1,460,020-1,460,416$ & S30 S60 & & \\
\hline & $0571(2815)$ & Pseudogene & Inside/antisense & $515,583-516,195$ & & & \\
\hline & $1122(5550)$ & DNA-directed RNA polymerase subunit beta & Inside/antisense & $1,036,085-1,036,594$ & & & \\
\hline & $1179(5820)$ & DNA repair protein RecN & Inside/sense & $1,089,736-1,089,641$ & & & \\
\hline & $1355(6685)$ & Transporter & Inside/sense & $1,259,390-1,259,212$ & & & \\
\hline & $1356(6690)$ & KxxxW cyclic peptide radical SAM maturase & Inside/sense & $1,260,895-1,260,614$ & & & W2 \\
\hline & $1520(7480)$ & $\begin{array}{l}\text { DNA internalization-related competence protein } \\
\text { ComEC/Rec } 2\end{array}$ & Inside/antisense & $1,425,795-1,426,019$ & $\mathrm{~S} 30$ & & \\
\hline & $1760(8600)$ & Transposase & Inside/antisense & $1,645,573-1,645,345$ & & & \\
\hline & $1921(9415)$ & ABC transporter ATP-binding protein & Promoter/antisense & $1,784,222-1,783,251$ & S30 S60 & & \\
\hline & $1978(9670)$ & $\begin{array}{l}\text { tRNA uridine-5-carboxymethylaminomethyl (34) } \\
\text { synthesis enzyme MnmG }\end{array}$ & Inside/antisense & $1,828,970-1,829,158$ & & & W4 \\
\hline
\end{tabular}

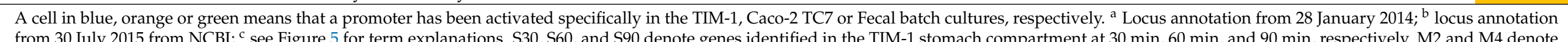
genes identified in fecal batch cultures from male volunteer at $2 \mathrm{~h}$ and $4 \mathrm{~h}$, respectively. W2 and W4 denote genes identified in fecal batch cultures from female volunteer at $2 \mathrm{~h}$ and $4 \mathrm{~h}$, respectively. 
3.6. Determination of Activated Gene Variability in S. thermophilus Strains Classified According to Their Resistance to GI Stresses and Adhesion Capacity

In a previous study, we determined the capacity of 30 phylogenetically very close strains of $S$. thermophilus to resist different stresses known to prevail in the human digestive tract (including acid stress) or to adhere to HT29-MTX mucus-producing cells. This led to the identification of six distinct phenotypic classes [15]. Therefore, we investigated the variability of activated genes from the present study in strains belonging to some of these six phenotypic groups. All genes identified in activated R-IVET clones from TIM-1, fecal batch cultures, or Caco-2 TC7 cells were amplified from the genomes of selected strains (CNRZ160, CNRZ21, EBL308, EBL385, EBLST20, PB18O, PB302, PB385, PB5MJ, ST14, and ST88; see Table 1). Sequences obtained were then compared with similar ones in fully sequenced LMD-9 and LMG18311 S. thermophilus strains [2,34].

As shown in Figure 6 (see full data in Table S3, Supplementary Materials), tested strains displayed three resistance levels against acid stress: high level (strains LMD-9, PB18O, PB302, EBLST20, and EBL385), low level (strains EBL308, ST14, and CNRZ21), and intermediate level (others) [15], with the most sensitive being strain CNRZ21. Out of the 24 genes tested and the 22 corresponding proteins, six (four proteins and two genes) were identical in all selected strains. On the contrary, 18 predicted proteins varied, among which 12 are encoded by genes specifically activated in TIM-1, three are encoded by genes specifically activated in fecal batch cultures, and three are encoded by genes activated in both models. They are involved in various functions such as nutrient absorption and metabolism, regulation of transcription, or stress response. Some of them correspond to hypothetical proteins (Table 3). Interestingly, strains displaying a high resistance level to acidity, especially LMD-9, PB18O, PB302, and EBLST20, shared greater similarity in allele profile than the most sensitive ones (EBL308, ST14, and CNRZ21). A protein signature could be deduced from a comparison of acid-resistant strains, which seemed less obvious for sensitive strains where more variability was observed (Figure 6 and Table S3, Supplementary Materials).

According to Junjua et al. [15], selected strains displayed also different adhesion capacities to HT29-MTX cells: high capacity for LMD-9, ST88, EBLST20, and LMG18311, intermediate capacity for PB18O and EBL385, and low capacity (unable to adhere) for CNRZ21 and PB5MJ. No clear difference was observed between strains depending on their adhesion capacity (Table S4, Supplementary Materials). Patterns obtained for the very adherent strains LMD-9, ST88, and EBLST20 were very similar, as well as similar to that of weakly adherent strains such as PB5MJ. Furthermore, the pattern obtained for the very adherent strain LMG18311 was very similar to that of the weakly adherent strain CNRZ21. This absence of variability might result from differences in cell models used in our work and Junjua et al. [15]. 
LMD-9d PB180 PB302 EBLST20 LMG18311 CNRZ160 PB385 EBL308 ST14 CNRZ21 EBL305

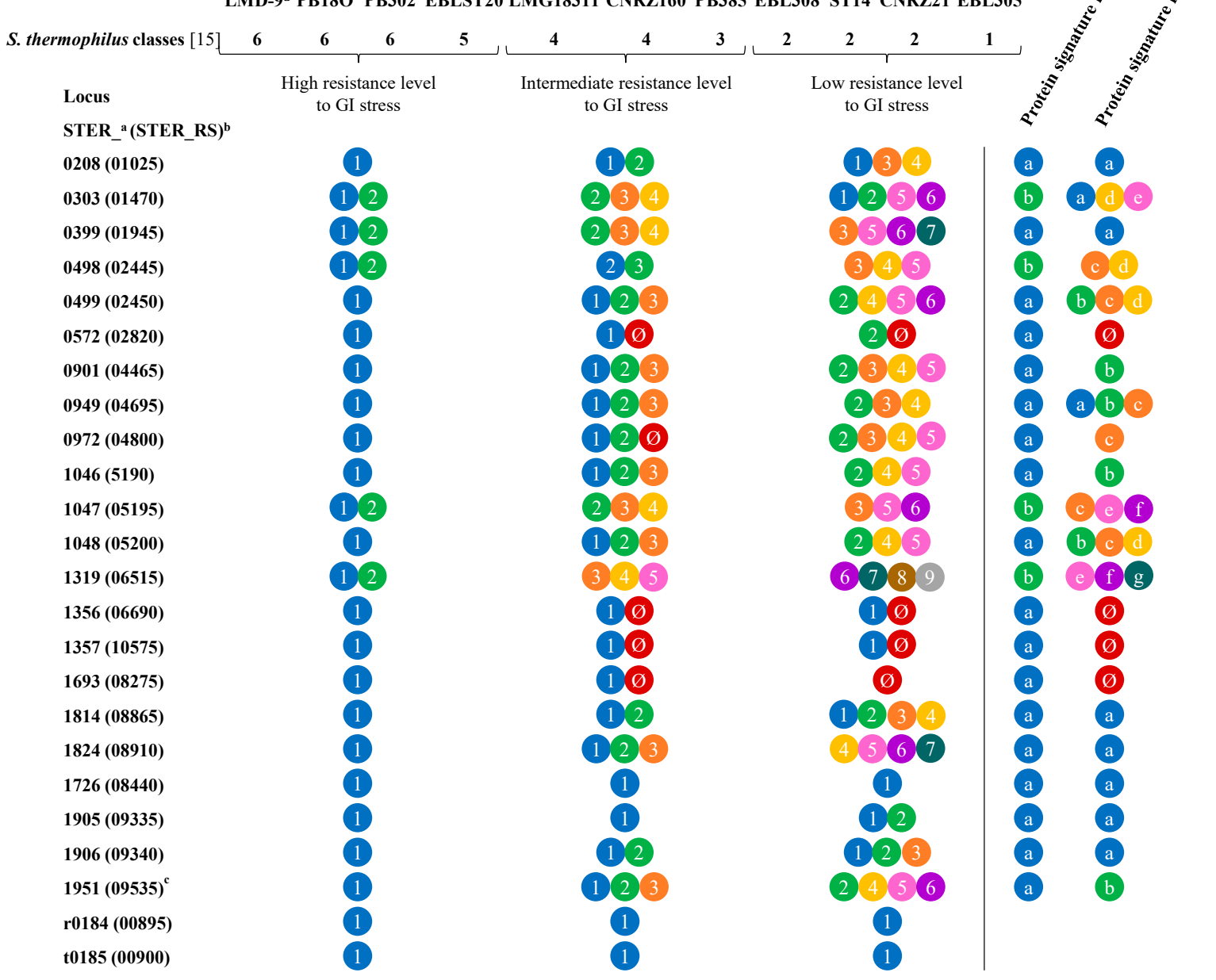

Figure 6. Schematic overview of allele variability of R-IVET activated genes identified in TIM-1 and fecal batch cultures among strains displaying different properties of resistance against GI stress and deduced protein signature. Colors/numbers correspond to different alleles of R-IVET activated genes that were identified. Different proteins signatures are given by different colors/letters. The full name of each gene is detailed in Table S3 (Supplementary Materials). ${ }^{\varnothing}$ No PCR amplicon; a locus annotation from 28 January 2014; ${ }^{b}$ locus annotation from 30 July 2015 from NCBI; ${ }^{\mathrm{c}}$ according to Junjua et al. [15]; ${ }^{d}$ LMD-9 used as a reference strain for comparison; ${ }^{e}$ types of proteins found in strains exhibiting a high level of resistance against GI stress; ${ }^{\text {f }}$ types of proteins found in strains exhibiting a low level of resistance against GI stress.

\section{Discussion}

The aim of this work was to better understand the physiological status of $S$. thermophilus during its passage through the human digestive environment. To reproduce the different niches found in the human GI tract, three complementary in vitro models were used, namely, the TIM-1 (stomach and small intestine), fecal batch cultures (colon), and the Caco-2 TC7 cells (interaction with intestinal epithelial cells). Among available approaches that allow the following of bacterial gene expression, we decided to use the R-IVET technology, which is the only one among IVET technologies that functions as a genetic screen [25]. The main advantage of this technology is that it makes it possible to identify genes specifically expressed in complex media, such as the human digestive environment, including transiently and locally expressed genes, at the level of the individual bacterium [25]. R-IVET also bypasses the difficult acquisition step of high-quality RNAs from complex environments required in other techniques (especially in environments with a complex microbial background as found in the human colon). First, we significantly improved the R-IVET tool applied to $S$. thermophilus LMD-9, through the construction 
and validation of a positive screening of activated clones. The LMD-9 reference strain was chosen for three main reasons: (i) availability of its genome sequence, (ii) ability to resist various stresses prevailing in the GI tract, and (iii) adherence to intestinal epithelial cells $[15,16,18,34]$. Then, we identified specifically activated genes in each digestive condition and observed that some of them varied across $S$. thermophilus strains showing different levels of resistance against GI stresses.

The chromosomal cassette we constructed allows the identification of activated genes through excision of the first reporter gene $s p e c R$, leading to the activation of the second reporter gene $k a n R$. Furthermore, by adding erythromycin to the selection medium already containing kanamycin, the activated $\operatorname{Spec}^{\mathrm{S}} \mathrm{Kan}^{\mathrm{R}}$ clones could be selected while ensuring the stability of the R-IVET plasmid. During this work, about 2500 clones displaying the $\mathrm{Spec}^{\mathrm{S}} \mathrm{Kan}^{\mathrm{R}} \mathrm{Ery}^{\mathrm{R}}$ phenotype were analyzed. In each of them, a precise excision of the $\operatorname{spec} R$ gene, through recombination between the lox sites flanking it, was observed, and an insert located upstream the cre gene was present, even though our genomic R-IVET library contained only $37.5 \%$ recombinant clones. This result provides a strong argument for the high stability of the constructed chromosomal cassette and the efficiency of designed screening approach. Lastly, the probability that genomic R-IVET library covered the entire LMD-9 genome was very high (0.997).

Identification of genes specifically activated under human simulated digestive conditions using R-IVET technology implies the elimination of any recombinant clone containing a promoter induced during its growth culture (i.e., before introduction in the tested environment). Despite our efforts, it was not possible to counterselect all $\mathrm{Spec}^{\mathrm{S}} \mathrm{Kan}^{\mathrm{R}}$ clones before introduction of the R-IVET library in each GI model, leading us to systematically analyze all these clones. This might result from the limited number of antibiotic resistance genes that can be efficiently used in $S$. thermophilus and constitutes a limitation of our R-IVET tool. Nevertheless, as shown in Table S2 (Supplementary Materials), inserts of T0 activated R-IVET clones often correspond to basic cellular functions expected to be activated during library growth, as bacteria have to display an active metabolism to multiply. Hence, promoters of the corresponding genes cloned upstream the cre gene are obviously activated.

Throughout in vitro experiments, among the $2424 \mathrm{Spec}^{\mathrm{S}} \mathrm{Kan}^{\mathrm{R}}$ clones analyzed, 128 promoters were detected, including 44 specifically activated in the GI models. All of these 44 promoters, expect one corresponding to a gene encoding a hypothetical protein of the phasin superfamily, appeared to be GI model-specific, strengthening the argument that they do not correspond to false positives. Furthermore, in each in vitro model, these promoters were represented several times among activated inserts. Thus, the first conclusion is that $S$. thermophilus LMD-9 is metabolically active and can finely adapt its metabolism to each of the tested digestive conditions. All of the 18 promoters identified in TIM- 1 were isolated from the gastric compartment, and no promoter was identified in the small intestine. This could be linked to a survival loss due to acidic $\mathrm{pH}$ in the stomach and high bile salt concentrations in the proximal small intestine. as the number of activated R-IVET clones that can be recovered is already weak, the significant drop in genomic library survival in the gastric and duodenal compartments might have contributed to the non-selection of activated clones. In the gastric compartment, $S$. thermophilus activated a higher number of genes involved in nutrient absorption and metabolism and in protein synthesis (10/18) compared to Caco-2 TC7 cells (3/20) and the colon model (2/6). Interestingly, while the gastric compartment was expected to be very stressful because of acidic conditions, only one gene (STER_0303) involved in stress response was identified (Figure 7). This gene might be involved in protecting cells against mutagenesis in relation to the HAM1 domain found in the last 200 amino-acid residues of the protein [43]. Detection of such a low number of stress-related genes could also result from adaptation to acidic conditions of the R-IVET library during its growth in milk, since, at the end of fermentation, $\mathrm{pH}$ was still low ( $\mathrm{pH}$ 4.6). Therefore, genes known to be involved in acidic stress resistance such as GroEL, GroES, or Hsp [44,45], activated from pH 5, were likely expressed during the growth phase, 
and the corresponding clones were eliminated during the counterselection step applied before TIM-1 inoculation. Of interest, an insert belonging to the groES gene was detected in an activated R-IVET clone; however, as it was a multi-insert clone, it was not included in the study. Even if there was only one stress protein induced, analysis of other genes activated during the TIM-1 gastric phase suggests an adaptation of the bacterium to very stressful conditions (Figure 7). As an example, the gene STER_1048 encodes a protein that displays a domain belonging to the superfamily of phasins, which are involved in many bacteria during formation and intracellular accumulation of polyhydroxyalkanoates under adverse conditions, which allows cells increasing their fitness and resistance to stresses [46].

Genes induced during adhesion assays suggest that $S$. thermophilus modulated its surface properties to adhere to Caco-2 TC7 cells (Figure 7). Three genes encoding cell surface proteins were induced during cell adhesion, two of them having an unknown function. The third was a cell membrane division protein designated as rod shape-determining protein RodA (STER_1197). This protein contains the FtsW domain [47], which appears to be required in crossing peptidoglycan precursors outside the cell membrane and for peptidoglycan biosynthesis, thus being involved in maintaining cell shape and modulating cell-wall morphology [48]. Furthermore, it has been shown that the RodA protein is essential for the cell viability of Bacillus subtilis and to maintain cell surface shape [49]. Three genes involved in nutrient absorption and metabolism were also induced; among them, one (STER_1494) encodes an ABC transporter [50]. Even if its role has to be further documented, it must be noted that a significant decrease in adhesion of B. bifidum to Caco-2 TC7 cells has been observed after deletion of ABC transporters encoding genes located at the outer cell surface [51].

Only six promoters were identified in batch cultures of human fecal microbiota. Two of them correspond to genes involved in protein synthesis, two encode stress proteins (STER_0572 and STER_1347 genes encoding two ABC permeases possibly involved in antimicrobial peptide transport; see [52]), and two encode proteins of the CRISPR immune system, one being an hypothetical protein while the other is the CRISPR-associated endoribonuclease Cas6. The activation of stress proteins and proteins from the CRISPR system involved in cell protection against foreign DNA, such as plasmid or virus DNA [53], suggests that $S$. thermophilus reacts to an environment where competition with other gut microorganisms is very hard (Figure 7).

Moreover, 54 unique inserts allowing the expression of the cre gene but not corresponding to an already annotated promoter region were revealed in gut models. There were three different cases for the location of insert sequence allowing Cre recombinase expression: (i) inside a gene and in the sense orientation, (ii) inside a gene but in the antisense orientation, and (iii) in the promoter region of a gene but on the antisense strand. All these inserts ere carefully analyzed using several predictive promoter software. In any case, there was at least one part of the sequence, located near the insert extremity and, hence, correctly positioned, that could serve as a promoter. Furthermore, analysis of the sequence located downstream revealed, in certain cases, the presence of small ORFs. The $S$. thermophilus genome is known to contain small ORFs encoding peptides involved in the regulation of response such as quorum sensing [54,55]. Thus, if their promoter activity is confirmed, these inserts could belong to regions containing small ORFs, not yet considered during genome annotation. Furthermore, sequences located inside a gene but in the antisense orientation could correspond to promoters of potential noncoding antisense RNA, as previously suggested in other studies using R-IVET technology, e.g., in L. plantarum [25] or Enterococcus faecalis [56,57]. As mentioned before, no Spec ${ }^{S} K_{a n}{ }^{R}$ clone obtained throughout this work was devoid of an insert. However, we cannot formally exclude that at least certain inserts corresponded to false positives as proposed by Koguchi et al. [27]. If we rule out the false positive hypothesis, then these data suggest the R-IVET technology as helpful for a better understanding of gene regulation, with potential use in genome annotation of a targeted strain such as $S$. thermophilus LMD-9. 


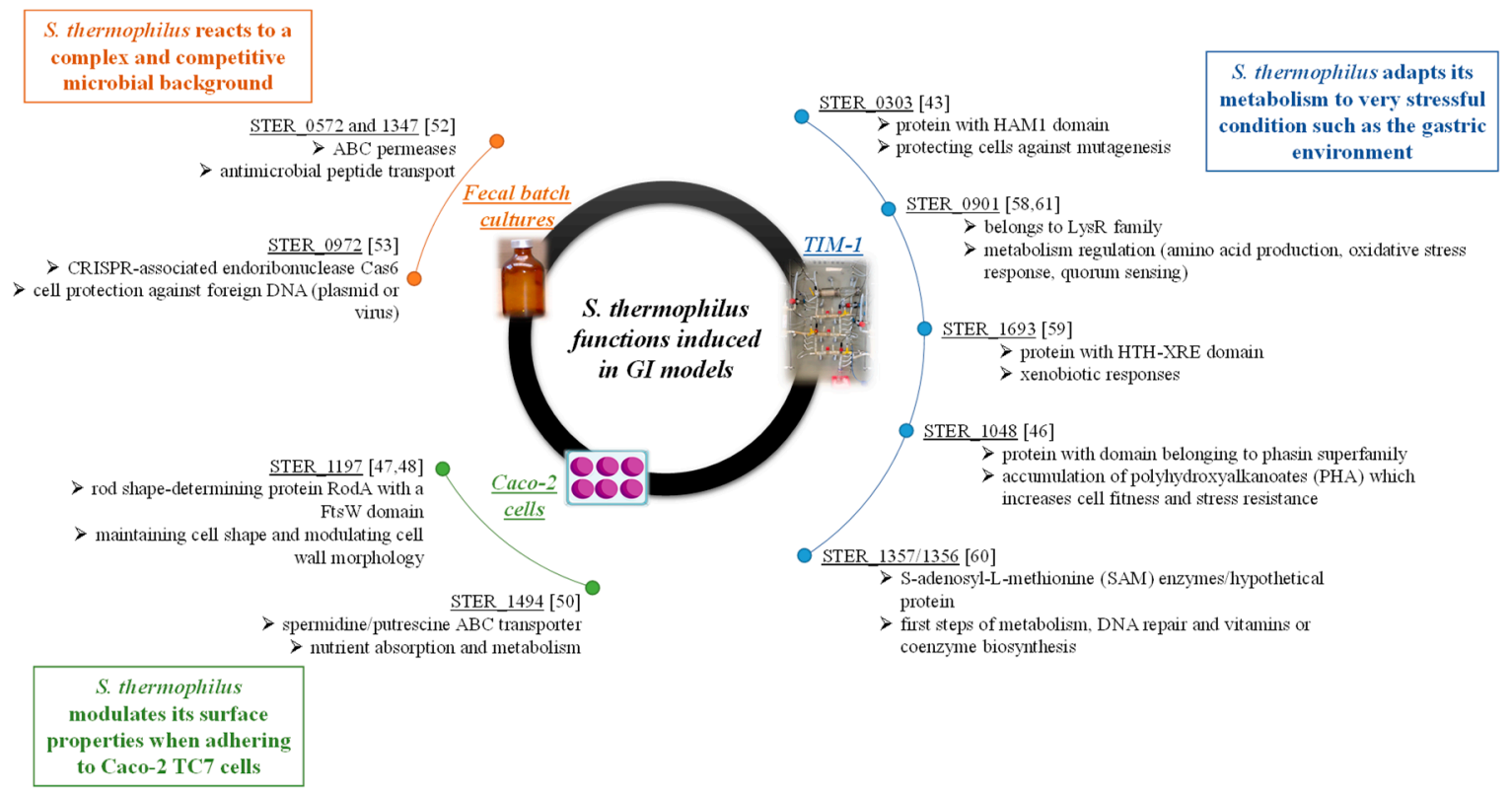

Figure 7. Synthetic view of main genes from S. thermophilus LMD-9 specifically induced in each GI models and their possible involvement in cell functions [43,46-48,50,52,53,58-61].

Lastly, we established the allelic form of the 44 genes revealed in GI models and deduced corresponding proteins in a collection of phylogenetically very close $S$. thermophilus strains [15]. These strains were previously described as displaying different survival capacities to known GI stresses (such as acidic $\mathrm{pH}$, bile salts, and oxidation stress) and varied adhesion capacity, although, in this last case, adhesion was determined using HT-29 MTX and not Caco-2 TC7 cells. For the 24 genes activated in TIM- 1 and fecal batch cultures, comparison of the corresponding proteins between strains having a high level and a low level of resistance to GI stresses allowed us to draw a protein signature for the two categories. The next step will be to determine their role in S. thermophilus resistance to GI conditions by making mutants and performing further experiments in TIM-1 and batch culture models. The ultimate goal of this study is to apply R-IVET technology to identify selection markers of GI resistance that will be helpful in the screening of $S$. thermophilus strains with potential probiotic properties.

Supplementary Materials: The following are available online at https:/ /www.mdpi.com/article/10 .3390/microorganisms9061113/s1: Figure S1. Survival of the R-IVET library in adhesion experiment conditions; Table S1. Oligonucleotides used for the constructions, verification of chromosomal R-IVET cassette, sequencing of inserts from activated clones, and amplification of activated genes in various S. thermophilus strains; Table S2. Inserts from activated R-IVET clones identified at T0 in the different gut models; Table S3. Allele variability of R-IVET activated genes identified in TIM-1 and fecal batch cultures; Table S4. Allele variability of R-IVET activated genes identified in Caco-2 TC7 cells.

Author Contributions: Conceptualization, S.B.-D. and A.D.-M.; data curation, A.D.-M., S.B.-D., O.U., M.G., M.K. and Z.H.; funding acquisition, S.B.-D. and A.D.-M.; investigation, O.U., M.K., W.G., M.G., E.L., S.D., S.C., Z.H. and E.R.; methodology, O.U., M.K., E.L., W.G., S.D., S.C., Z.H., E.R., M.G., S.B.-D. and A.D.-M.; formal analysis, O.U., M.K., E.L., Z.H. and M.G.; validation, O.U., M.K., S.D., M.G., S.B.-D. and A.D.-M.; writing-original draft preparation, O.U. and M.K.; writing-review and editing, O.U., M.K., S.D., Z.H., E.R., M.G., S.B.-D. and A.D.-M.; supervision, M.G., A.D.-M. and S.B.-D. All authors have read and agreed to the published version of the manuscript.

Funding: Ophélie Uriot (O.U.) and Mounira Kebouchi (M.K.) were the recipients of a PhD fellowship from the Ministère de l'Enseignement Supérieur, de la Recherche, et de l'Innovation. 
Institutional Review Board Statement: Not applicable. This study being a non-interventional study with no addition to usual clinical care, according to the French Health Public Law (CSP Art L 1121-1.1), the protocol does not require approval from an ethic committee.

Informed Consent Statement: Informed consent was obtained from all subjects involved in the study. Data Availability Statement: Not applicable.

Conflicts of Interest: The authors declare no conflict of interest.

\section{References}

1. Cui, Y.; Xu, T.; Qu, X.; Hu, T.; Jiang, X.; Zhao, C. New Insights into Various Production Characteristics of Streptococcus Thermophilus Strains. Int. J. Mol. Sci. 2016, 17, 1701. [CrossRef] [PubMed]

2. Bolotin, A.; Quinquis, B.; Renault, P.; Sorokin, A.; Ehrlich, S.D.; Kulakauskas, S.; Lapidus, A.; Goltsman, E.; Mazur, M.; Pusch, G.D.; et al. Complete Sequence and Comparative Genome Analysis of the Dairy Bacterium Streptococcus Thermophilus. Nat. Biotechnol. 2004, 22, 1554-1558. [CrossRef] [PubMed]

3. EFSA Panel on Dietetic Products, Nutrition and Allergies (NDA); Scientific Opinion on the Substantiation of Health Claims Related to Live Yoghurt Cultures and Improved Lactose Digestion (ID 1143, 2976) Pursuant to Article 13(1) of Regulation (EC) No 1924/2006. EFSA J. 2010, 8, 1763. [CrossRef]

4. Guarner, F.; Perdigon, G.; Corthier, G.; Salminen, S.; Koletzko, B.; Morelli, L. Should Yoghurt Cultures Be Considered Probiotic? Br. J. Nutr. 2005, 93, 783. [CrossRef]

5. Hill, C.; Guarner, F.; Reid, G.; Gibson, G.R.; Merenstein, D.J.; Pot, B.; Morelli, L.; Canani, R.B.; Flint, H.J.; Salminen, S.; et al. Expert Consensus Document. The International Scientific Association for Probiotics and Prebiotics Consensus Statement on the Scope and Appropriate Use of the Term Probiotic. Nat. Rev. Gastroenterol. Hepatol. 2014, 11, 506-514. [CrossRef]

6. FAO/WHO Food and Agricultural Organization of the United Nations and World Health Organization. Joint FAO/WHO Working Group Report on Drafting Guidelines for the Evaluation of Probiotics in Food; Food and Agricultural Organization of the United Nations: 2002. Available online: https: / / www.who.int/foodsafety/fs_management/en/probiotic_guidelines.pdf (accessed on 20 May 2021).

7. Mater, D.D.; Bretigny, L.; Firmesse, O.; Flores, M.-J.; Mogenet, A.; Bresson, J.-L.; Corthier, G. Streptococcus Thermophilus and Lactobacillus Delbrueckii Subsp. Bulgaricus Survive Gastrointestinal Transit of Healthy Volunteers Consuming Yogurt. FEMS Microbiol. Lett. 2005, 250, 185-187. [CrossRef]

8. Elli, M.; Callegari, M.L.; Ferrari, S.; Bessi, E.; Cattivelli, D.; Soldi, S.; Morelli, L.; Goupil Feuillerat, N.; Antoine, J.-M. Survival of Yogurt Bacteria in the Human Gut. Appl. Environ. Microbiol. 2006, 72, 5113-5117. [CrossRef]

9. García-Hernández, J.; Moreno, Y.; Chuan, C.; Hernández, M. In Vivo Study of the Survival of Lactobacillus Delbrueckii Subsp. Bulgaricus CECT 4005T and Streptococcus Thermophilus CECT 801 by DVC-FISH after Consumption of Fermented Milk. J. Food Sci. 2012, 77, M593-597. [CrossRef]

10. Martinović, A.; Cocuzzi, R.; Arioli, S.; Mora, D. Streptococcus Thermophilus: To Survive, or Not to Survive the Gastrointestinal Tract, That Is the Question! Nutrients 2020, 12, 2175. [CrossRef] [PubMed]

11. Nagpal, R.; Kumar, A.; Kumar, M.; Behare, P.V.; Jain, S.; Yadav, H. Probiotics, Their Health Benefits and Applications for Developing Healthier Foods: A Review. FEMS Microbiol. Lett. 2012, 334, 1-15. [CrossRef] [PubMed]

12. Miquel, S.; Beaumont, M.; Martín, R.; Langella, P.; Braesco, V.; Thomas, M. A Proposed Framework for an Appropriate Evaluation Scheme for Microorganisms as Novel Foods with a Health Claim in Europe. Microb. Cell Factories 2015, 14, 48. [CrossRef] [PubMed]

13. Couvigny, B.; Thérial, C.; Gautier, C.; Renault, P.; Briandet, R.; Guédon, E. Streptococcus Thermophilus Biofilm Formation: A Remnant Trait of Ancestral Commensal Life? PLoS ONE 2015, 10, e0128099. [CrossRef]

14. Guigas, C.; Faulhaber, K.; Duerbeck, D.; Neve, H.; Heller, K.J. Prophage-Mediated Modulation of Interaction of Streptococcus Thermophilus J34 with Human Intestinal Epithelial Cells and Its Competition against Human Pathogens. Benef. Microbes 2016, 7, 289-297. [CrossRef]

15. Junjua, M.; Kechaou, N.; Chain, F.; Awussi, A.A.; Roussel, Y.; Perrin, C.; Roux, E.; Langella, P.; Bermúdez-Humarán, L.G.; Le Roux, Y.; et al. A Large Scale in Vitro Screening of Streptococcus Thermophilus Strains Revealed Strains with a High Anti-Inflammatory Potential. LWT Food Sci. Technol. 2016, 70, 78-87. [CrossRef]

16. Kebouchi, M.; Galia, W.; Genay, M.; Soligot, C.; Lecomte, X.; Awussi, A.A.; Perrin, C.; Roux, E.; Dary-Mourot, A.; Le Roux, Y. Implication of Sortase-Dependent Proteins of Streptococcus Thermophilus in Adhesion to Human Intestinal Epithelial Cell Lines and Bile Salt Tolerance. Appl. Microbiol. Biotechnol. 2016, 100, 3667-3679. [CrossRef]

17. Uriot, O.; Denis, S.; Junjua, M.; Roussel, Y.; Dary-Mourot, A.; Blanquet-Diot, S. Streptococcus Thermophilus: From Yogurt Starter to a New Promising Probiotic Candidate? J. Funct. Foods 2017, 37, 74. [CrossRef]

18. Uriot, O.; Galia, W.; Awussi, A.A.; Perrin, C.; Denis, S.; Chalancon, S.; Lorson, E.; Poirson, C.; Junjua, M.; Le Roux, Y.; et al. Use of the Dynamic Gastro-Intestinal Model TIM to Explore the Survival of the Yogurt Bacterium Streptococcus Thermophilus and the Metabolic Activities Induced in the Simulated Human Gut. Food Microbiol. 2016, 53, 18-29. [CrossRef]

19. Zhang, J.; Liu, M.; Xu, J.; Qi, Y.; Zhao, N.; Fan, M. First Insight into the Probiotic Properties of Ten Streptococcus Thermophilus Strains Based on In Vitro Conditions. Curr. Microbiol. 2020, 77, 343-352. [CrossRef] 
20. Rul, F.; Ben-Yahia, L.; Chegdani, F.; Wrzosek, L.; Thomas, S.; Noordine, M.-L.; Gitton, C.; Cherbuy, C.; Langella, P.; Thomas, M. Impact of the Metabolic Activity of Streptococcus Thermophilus on the Colon Epithelium of Gnotobiotic Rats. J. Biol. Chem. 2011, 286, 10288-10296. [CrossRef]

21. Thomas, M.; Wrzosek, L.; Ben-Yahia, L.; Noordine, M.-L.; Gitton, C.; Chevret, D.; Langella, P.; Mayeur, C.; Cherbuy, C.; Rul, F. Carbohydrate Metabolism Is Essential for the Colonization of Streptococcus Thermophilus in the Digestive Tract of Gnotobiotic Rats. PLoS ONE 2011, 6, e28789. [CrossRef]

22. Camilli, A.; Beattie, D.T.; Mekalanos, J.J. Use of Genetic Recombination as a Reporter of Gene Expression. Proc. Natl. Acad. Sci. USA 1994, 91, 2634-2638. [CrossRef]

23. Junjua, M.; Galia, W.; Gaci, N.; Uriot, O.; Genay, M.; Bachmann, H.; Kleerebezem, M.; Dary, A.; Roussel, Y. Development of the Recombinase-Based in Vivo Expression Technology in Streptococcus Thermophilus and Validation Using the Lactose Operon Promoter. J. Appl. Microbiol. 2014, 116, 620-631. [CrossRef]

24. Lee, S.H.; Hava, D.L.; Waldor, M.K.; Camilli, A. Regulation and Temporal Expression Patterns of Vibrio Cholerae Virulence Genes during Infection. Cell 1999, 99, 625-634. [CrossRef]

25. Bron, P.A.; Grangette, C.; Mercenier, A.; de Vos, W.M.; Kleerebezem, M. Identification of Lactobacillus Plantarum Genes that Are Induced in the Gastrointestinal Tract of Mice. J. Bacteriol. 2004, 186, 5721-5729. [CrossRef]

26. Osorio, C.G.; Crawford, J.A.; Michalski, J.; Martinez-Wilson, H.; Kaper, J.B.; Camilli, A. Second-Generation Recombination-Based in Vivo Expression Technology for Large-Scale Screening for Vibrio Cholerae Genes Induced during Infection of the Mouse Small Intestine. Infect. Immun. 2005, 73, 972-980. [CrossRef]

27. Koguchi, H.; Ishigami, N.; Sakanaka, M.; Yoshida, K.; Hiratou, S.; Shimada, M.; Fukiya, S.; Sonoyama, K.; Yokota, A. Application of Recombinase-Based in Vivo Expression Technology to Bifidobacterium Longum Subsp. Longum for Identification of Genes Induced in the Gastrointestinal Tract of Mice. Microorganisms 2020, 8, 410. [CrossRef]

28. Guerra, A.; Etienne-Mesmin, L.; Livrelli, V.; Denis, S.; Blanquet-Diot, S.; Alric, M. Relevance and Challenges in Modeling Human Gastric and Small Intestinal Digestion. Trends Biotechnol. 2012, 30, 591-600. [CrossRef]

29. Cordonnier, C.; Thévenot, J.; Etienne-Mesmin, L.; Denis, S.; Alric, M.; Livrelli, V.; Blanquet-Diot, S. Dynamic in Vitro Models of the Human Gastrointestinal Tract as Relevant Tools to Assess the Survival of Probiotic Strains and Their Interactions with Gut Microbiota. Microorganisms 2015, 3, 725-745. [CrossRef]

30. Naimi, S.; Zirah, S.; Hammami, R.; Fernandez, B.; Rebuffat, S.; Fliss, I. Fate and Biological Activity of the Antimicrobial Lasso Peptide Microcin J25 Under Gastrointestinal Tract Conditions. Front. Microbiol. 2018, 9. [CrossRef]

31. Sambuy, Y.; De Angelis, I.; Ranaldi, G.; Scarino, M.L.; Stammati, A.; Zucco, F. The Caco-2 Cell Line as a Model of the Intestinal Barrier: Influence of Cell and Culture-Related Factors on Caco-2 Cell Functional Characteristics. Cell Biol. Toxicol. 2005, 21, 1-26. [CrossRef]

32. Terzaghi, B.E.; Sandine, W.E. Improved Medium for Lactic Streptococci and Their Bacteriophages. Appl. Microbiol. 1975, 29, 807-813. [CrossRef] [PubMed]

33. Gardan, R.; Besset, C.; Guillot, A.; Gitton, C.; Monnet, V. The Oligopeptide Transport System Is Essential for the Development of Natural Competence in Streptococcus Thermophilus Strain LMD-9. J. Bacteriol. 2009, 191, 4647-4655. [CrossRef]

34. Makarova, K.; Slesarev, A.; Wolf, Y.; Sorokin, A.; Mirkin, B.; Koonin, E.; Pavlov, A.; Pavlova, N.; Karamychev, V.; Polouchine, N.; et al. Comparative Genomics of the Lactic Acid Bacteria. Proc. Natl. Acad. Sci. USA 2006, 103, 15611-15616. [CrossRef]

35. Takamatsu, D.; Osaki, M.; Sekizaki, T. Thermosensitive Suicide Vectors for Gene Replacement in Streptococcus Suis. Plasmid 2001, 46, 140-148. [CrossRef]

36. Fischer, G.; Decaris, B.; Leblond, P. Occurrence of Deletions, Associated with Genetic Instability in Streptomyces Ambofaciens, Is Independent of the Linearity of the Chromosomal DNA. J. Bacteriol. 1997, 179, 4553-4558. [CrossRef]

37. Sambrook, J.; Fritsch, E.F.; Maniatis, T.; Cold Spring Harbor Laboratory. Molecular Cloning: A Laboratory Manual; Cold Spring Harbor Laboratory Press: New York, NY, USA, 1989.

38. Thévenot, J.; Cordonnier, C.; Rougeron, A.; Le Goff, O.; Nguyen, H.T.T.; Denis, S.; Alric, M.; Livrelli, V.; Blanquet-Diot, S. Enterohemorrhagic Escherichia Coli Infection Has Donor-Dependent Effect on Human Gut Microbiota and May Be Antagonized by Probiotic Yeast during Interaction with Peyer's Patches. Appl. Microbiol. Biotechnol. 2015, 99, 9097-9110. [CrossRef] [PubMed]

39. Solovyev, V.; Salamov, A. Automatic Annotation of Microbial Genomes and Metagenomic Sequences. In Metagenomics and Its Applications in Agriculture, Biomedicine and Environmental Studies; Li, R.W., Ed.; Nova Science Publishers: New York, NY, USA, 2011; pp. 61-78. ISBN 978-1-61668-682-6.

40. Klucar, L.; Stano, M.; Hajduk, M. PhiSITE: Database of Gene Regulation in Bacteriophages. Nucleic Acids Res. 2010, 38, D366D370. [CrossRef]

41. Clarke, L.; Carbon, J. A Colony Bank Containing Synthetic CoI EI Hybrid Plasmids Representative of the Entire E. Coli Genome. Cell 1976, 9, 91-99. [CrossRef]

42. Ben-Yahia, L.; Mayeur, C.; Rul, F.; Thomas, M. Growth Advantage of Streptococcus Thermophilus over Lactobacillus Bulgaricus in Vitro and in the Gastrointestinal Tract of Gnotobiotic Rats. Benef. Microbes 2012, 3, 211-219. [CrossRef]

43. NCBI Conserved Domain Search. Available online: www.ncbi.nlm.nih.gov/Structure/cdd/wrpsb.cgi?INPUT_TYPE=live\& SEQUENCE=WP_011226850.1 (accessed on 7 May 2021). 
44. Arena, S.; D'Ambrosio, C.; Renzone, G.; Rullo, R.; Ledda, L.; Vitale, F.; Maglione, G.; Varcamonti, M.; Ferrara, L.; Scaloni, A. A Study of Streptococcus Thermophilus Proteome by Integrated Analytical Procedures and Differential Expression Investigations. Proteomics 2006, 6, 181-192. [CrossRef]

45. Zotta, T.; Ricciardi, A.; Ciocia, F.; Rossano, R.; Parente, E. Diversity of Stress Responses in Dairy Thermophilic Streptococci. Int. J. Food Microbiol. 2008, 124, 34-42. [CrossRef]

46. de Almeida, A.; Nikel, P.I.; Giordano, A.M.; Pettinari, M.J. Effects of Granule-Associated Protein PhaP on Glycerol-Dependent Growth and Polymer Production in Poly(3-Hydroxybutyrate)-Producing Escherichia Coli. Appl. Environ. Microbiol. 2007, 73, 7912-7916. [CrossRef]

47. NCBI Conserved Domain Search. Available online: www.ncbi.nlm.nih.gov/Structure/cdd/wrpsb.cgi?INPUT_TYPE=live\& SEQUENCE=WP_011681262.1 (accessed on 7 May 2021).

48. Ishino, F.; Park, W.; Tomioka, S.; Tamaki, S.; Takase, I.; Kunugita, K.; Matsuzawa, H.; Asoh, S.; Ohta, T.; Spratt, B.G. Peptidoglycan Synthetic Activities in Membranes of Escherichia Coli Caused by Overproduction of Penicillin-Binding Protein 2 and RodA Protein. J. Biol. Chem. 1986, 261, 7024-7031. [CrossRef]

49. Henriques, A.O.; Glaser, P.; Piggot, P.J.; Moran, C.P. Control of Cell Shape and Elongation by the RodA Gene in Bacillus Subtilis. Mol. Microbiol. 1998, 28, 235-247. [CrossRef] [PubMed]

50. NCBI Conserved Domain Search. Available online: www.ncbi.nlm.nih.gov/Structure/cdd/wrpsb.cgi?INPUT_TYPE=live\& SEQUENCE=WP_011681478.1 (accessed on 7 May 2021).

51. Guglielmetti, S.; Tamagnini, I.; Mora, D.; Minuzzo, M.; Scarafoni, A.; Arioli, S.; Hellman, J.; Karp, M.; Parini, C. Implication of an Outer Surface Lipoprotein in Adhesion of Bifidobacterium Bifidum to Caco-2 Cells. Appl. Environ. Microbiol. 2008, 74, 4695-4702. [CrossRef] [PubMed]

52. NCBI Conserved Domain Search. Available online: www.ncbi.nlm.nih.gov/Structure/cdd/wrpsb.cgi?INPUT_TYPE=live\& SEQUENCE=ABJ65842.1 (accessed on 16 May 2020).

53. Hochstrasser, M.L.; Doudna, J.A. Cutting It Close: CRISPR-Associated Endoribonuclease Structure and Function. Trends Biochem. Sci. 2015, 40, 58-66. [CrossRef]

54. Ibrahim, M.; Guillot, A.; Wessner, F.; Algaron, F.; Besset, C.; Courtin, P.; Gardan, R.; Monnet, V. Control of the Transcription of a Short Gene Encoding a Cyclic Peptide in Streptococcus Thermophilus: A New Quorum-Sensing System? J. Bacteriol. 2007, 189, 8844-8854. [CrossRef]

55. Ibrahim, M.; Nicolas, P.; Bessières, P.; Bolotin, A.; Monnet, V.; Gardan, R. A Genome-Wide Survey of Short Coding Sequences in Streptococci. Microbiol. Read. Engl. 2007, 153, 3631-3644. [CrossRef]

56. Hanin, A.; Sava, I.; Bao, Y.; Huebner, J.; Hartke, A.; Auffray, Y.; Sauvageot, N. Screening of in Vivo Activated Genes in Enterococcus Faecalis during Insect and Mouse Infections and Growth in Urine. PLoS ONE 2010, 5, e11879. [CrossRef]

57. Frank, K.L.; Barnes, A.M.T.; Grindle, S.M.; Manias, D.A.; Schlievert, P.M.; Dunny, G.M. Use of Recombinase-Based in Vivo Expression Technology to Characterize Enterococcus Faecalis Gene Expression during Infection Identifies in Vivo-Expressed Antisense RNAs and Implicates the Protease Eep in Pathogenesis. Infect. Immun. 2012, 80, 539-549. [CrossRef]

58. NCBI Conserved Domain Search. Available online: www.ncbi.nlm.nih.gov/Structure/cdd/wrpsb.cgi?INPUT_TYPE=live\& SEQUENCE=WP_011681073.1 (accessed on 7 May 2021).

59. NCBI Conserved Domain Search. Available online: www.ncbi.nlm.nih.gov/Structure/cdd/wrpsb.cgi?INPUT_TYPE=live\& SEQUENCE=WP_011681604.1 (accessed on 7 May 2021).

60. Ding, W.; Ji, X.; Li, Y.; Zhang, Q. Catalytic Promiscuity of the Radical S-Adenosyl-L-Methionine Enzyme NosL. Front. Chem. 2016, 4, 27. [CrossRef]

61. Maddocks, S.E.; Oyston, P.C.F. Structure and Function of the LysR-Type Transcriptional Regulator (LTTR) Family Proteins. Microbiol. Read. Engl. 2008, 154, 3609-3623. [CrossRef] 